\title{
LRP-1 and LRP-2 receptors function in the membrane neuron. Trafficking mechanisms and proteolytic processing in Alzheimer's disease
}

\section{Carlos Spuch*, Saida Ortolano and Carmen Navarro}

Department of Pathology and Neuropathology, University Hospital of Vigo, Vigo, Spain

\section{Edited by:}

Raquel Marin, Universidad de La

Laguna, Spain

Reviewed by:

Lillian DeBruin, Wilfrid Laurier

University, Canada

Josef Berger, University of South

Bohemia, Czech Republic

\section{*Correspondence:}

Carlos Spuch, Department of Pathology and Neuropathology,

Complejo Hospitalario Universitario de Vigo (CHUVI), Hospital of

Meixoeiro, Meixoeiro s/n, 36215

Vigo, Spain

e-mail: carlos.spuch@gmail.com; carlos.spuch.calvar@sergas.es
Low density lipoprotein receptor-related protein (LRP) belongs to the low-density lipoprotein receptor family, generally recognized as cell surface endocytic receptors, which bind and internalize extracellular ligands for degradation in lysosomes. Neurons require cholesterol to function and keep the membrane rafts stable. Cholesterol uptake into the neuron is carried out by ApoE via LRPs receptors on the cell surface. In neurons the most important are LRP-1 and LRP-2, even it is thought that a causal factor in Alzheimer's disease $(A D)$ is the malfunction of this process which cause impairment intracellular signaling as well as storage and/or release of nutrients and toxic compounds. Both receptors are multifunctional cell surface receptors that are widely expressed in several tissues including neurons and astrocytes. LRPs are constituted by an intracellular (ICD) and extracellular domain (ECD). Through its ECD, LRPs bind at least 40 different ligands ranging from lipoprotein and protease inhibitor complex to growth factors and extracellular matrix proteins. These receptors has also been shown to interact with scaffolding and signaling proteins via its ICD in a phosphorylation-dependent manner and to function as a co-receptor partnering with other cell surface or integral membrane proteins. Thus, LRPs are implicated in two major physiological processes: endocytosis and regulation of signaling pathways, which are both involved in diverse biological roles including lipid metabolism, cell growth processes, degradation of proteases, and tissue invasion. Interestingly, LRPs were also localized in neurons in different stages, suggesting that both receptors could be implicated in signal transduction during embryonic development, neuronal outgrowth or in the pathogenesis of AD.

Keywords: Alzheimer's disease, astrocytes, amyloid-beta, intracellular domain, LRP-1, LRP-2, megalin, central nervous system, brain, neurodegenerative diseases, neuron

\section{THE LOW-DENSITY LIPOPROTEIN RECEPTOR (LDLR) FAMILY}

The LDLR family consists of more than 11 receptors that function in receptor-mediated endocytosis and cellular signaling (Herz and Bock, 2002). In addition to the LDLR itself, the family includes LRP1 (Herz et al., 1988), LRP-2, also called megalin, (Spuch and Navarro, 2010a,b), VLDLR (Takakashi et al., 1992), LRP5 (Hey et al., 1998; Kim et al., 1998), LRP6 (Brown et al., 1998), ApoE receptor 2 (ApoER2), also called LRP8 (Kim et al., 1996; Novak et al., 1996; Brandes et al., 1997), sorLA-1, also called LR11, (Jakobsen et al., 1996; Yamazaki et al., 1996), LRP1B (Liu et al., 2000) and the most recently identified the LRAD3 (Ranganathan et al., 2011). A model depicting the major structural components of the representative receptors is shown in Figure 1.

\section{LOW DENSITY LIPOPROTEIN RECEPTOR-RELATED PROTEIN-1 (LRP1)}

The LRP1, also known as CD91 or $\alpha 2$ macroglobulin receptor, is a multifunctional scavenger and signaling receptor that belongs to the LRP family (Bruno et al., 2010; Boucher and Herz, 2011). LRP1 is a massive protein $(600 \mathrm{kDa})$ that is proteolytically nicked during biosynthesis to give two stably associated polypeptides: an $85-\mathrm{kDa}$ membrane-spanning C-terminal fragment and a $515-\mathrm{kDa}$ extracellular $\mathrm{N}$-terminal chain. The extracellular heavy $\alpha$-chain of LRP1 is non-covalently coupled to the transmembrane and cytoplasmic light $\beta$-chain domain. The $\alpha$-chain contains four ligand-binding domains (clusters 1-4), consisting of 2,8 , 10 , and 11 cysteine-rich complement-type repeats, respectively (Obermoeller-McCormick et al., 2001) (Figure 1). The LRP1 ligand-binding domains 2 and 4 are the major LRP1 binding regions interacting with a diverse array of approximately forty structurally diverse ligands. LRP1 is expressed abundantly on neurons (Moestrup and Verroust, 2001; Kanekiyo et al., 2011), where its fundamental role is the uptake of cholesterol and fatty acids required for synapse formation (Mauch et al., 2001; Fester et al., 2009). In addition, LRP1 binds more than 30 ligands extracellularly, including ApoE, $\alpha 2$-macroglobulin, tissue plasminogen activator (tPA), proteinase-inhibitors, blood coagulation factors, receptor-associated protein (RAP), $\mathrm{A} \beta$, prion protein and aprotinin (Hussain et al., 1999; Neels et al., 1999; Herz, 2001; Herz and Strickland, 2001; Croy et al., 2003; Deane et al., 2004a,b; Meijer et al., 2007; Demeule et al., 2008; Lillis et al., 2008; Parkyn 


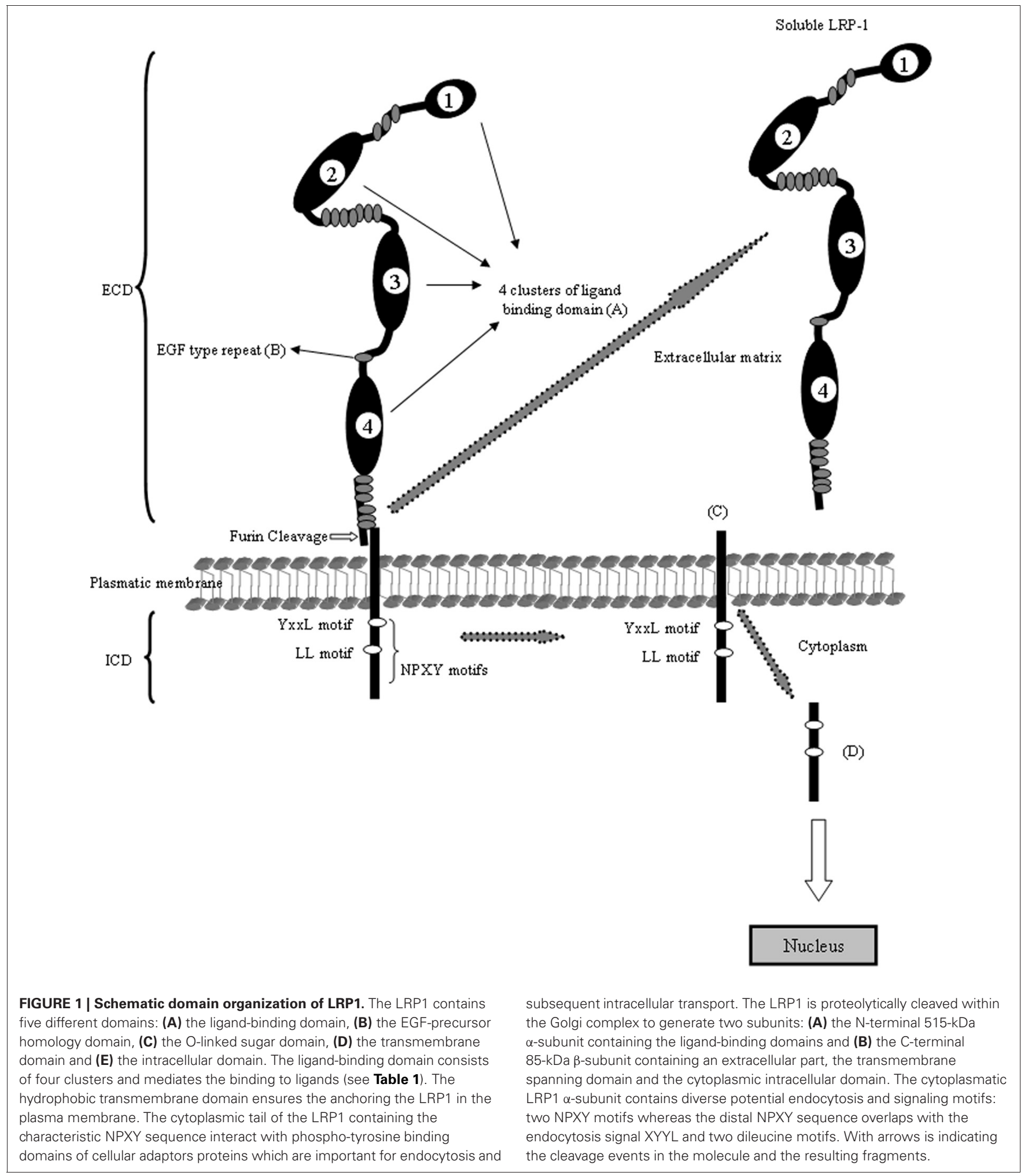

et al., 2008) (Table 1). Interestingly, its cytoplasmic domain binds to endocytic and scaffold adaptors that link the receptor to other membrane proteins, including Amyloid Precursor Protein (APP) (Herz and Chen, 2006; Waldron et al., 2008). The cytoplasmic tail of LRP1 contains two NPXY motifs, one YXXL motif and two di-leucine motifs (Li et al., 2001). It has been suggested that these motifs may be associated with the rapid endocytotic rate of LRP1 (Deane et al., 2008). The cytoplasmic tail is phosphorylated on serine and/or tyrosine residues (van der Geer, 2002) and can interact with different adaptor proteins associated with cell 
Table 1 | Ligands of LRP1 and LRP2.

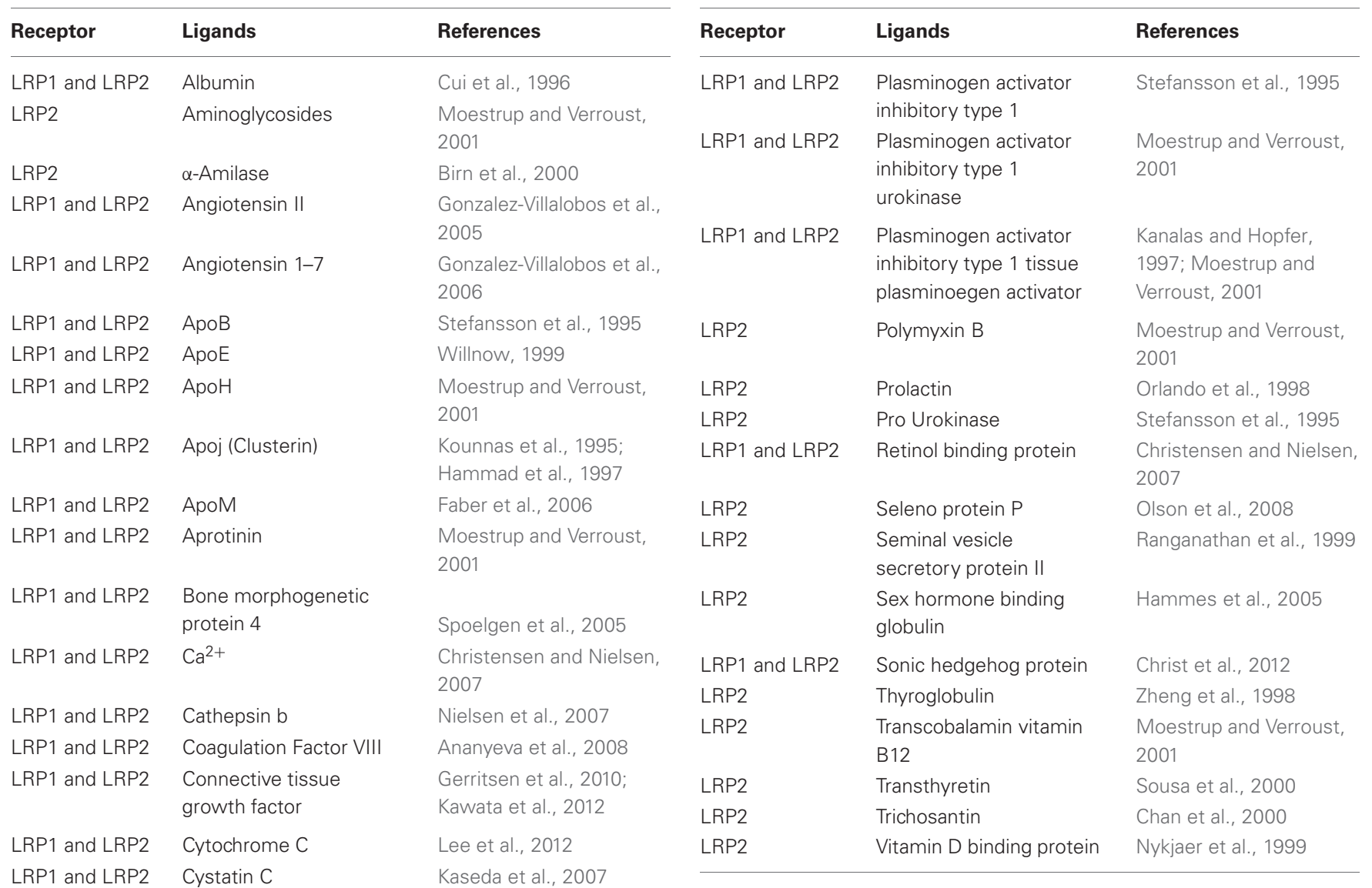

LRP1 and LRP2 Epidermal growth factor

LRP1 and LRP2 Folate binding protein

LRP1 Frizzled-1

LRP2 $\quad \alpha$-galactosidase

LRP2 Gelsolin

LRP1 and LRP2 Hemoglobin

LRP1 and LRP2 Insulin

LRP2

LRP1 and LRP2

LRP1 and LRP2

LRP1 and LRP2

LRP2

LRP2

LRP1 and LRP2

LRP2

LRP2

LRP2

LRP2

LRP2

LRP2

LRP1 and LRP2
Insulin Growth factor I

Lactoferrin

Leptin

Lipoprotein lipase

Liver type fatty acid

binding protein

Lysozyme

Metallothionein

Microglobulin

Myoglobulin

Neutrophil gelatinase associated lipocalin

Odorant binding protein

Parathyroid hormone

Pancreatitis associated protein 1

Plasminogen
Table 1 | Contined

signaling, such as disabled-1 (Dab1), FE65 (Klug et al., 2011) and postsynaptic density protein 95 (PSD95) (Trommsdorff et al., 1998; Gotthardt et al., 2000; Herz et al., 2009). Thus, LRP1 has a dual role as a receptor which internalizes its ligands acting like a rapid cargo endocytotic cellular transporter and also as transmembrane cell signaling receptor (Pflanzner et al., 2011).

\section{LRP1 expression in the brain}

LRP1 is highly expressed in neurons (Andersen and Willnow, 2006), mainly of the entorhinal cortex, hippocampus and cerebellum, activated astrocytes (Rebeck et al., 1995), and microglia (Marzolo et al., 2000). Importantly, LRP1 is further expressed in the central nervous system in different cell types within the neurovascular unit including vascular cells such as brain endothelial cells, vascular smooth muscle cells and pericytes, and it is also expressed in the choroid plexus of the blood-brain barrier (BBB) (Herz and Bock, 2002).

\section{LRP1 and signal transduction in the brain}

In neurons LRP1 is mainly implicated promoting local catabolism of $A \beta$. LRP1 is found in the somatodendritic compartment of neurons (Brown et al., 1997), and it can mediate the endocytosis of extracellular ligands in these cells (Makarova et al., 2003). LRP1 also interacts with the neuronally expressed APP (Knauer et al., 1996; Kinoshita et al., 2001) and regulates its proteolytical processing as well as the production of the $\mathrm{A} \beta$ peptide (Pietrzik 
et al., 2002), a process that is of central importance for the pathogenesis of AD. Direct binding of LRP1 to the APP has been shown to affect endoproteolytic processing of APP to increase the production of A $\beta 42$ peptides (Rebeck et al., 2001), which are the major constituent of amyloid plaques (Iwatsubo et al., 1994). LRP1 can promote A $\beta$ production by altering the processing of APP through interactions via the Kunitz protease inhibitor (KPI) domain. Although the non-KPI-APP isoform can weakly bind to LRP1 through cytoplasmic adaptor proteins, such as FE65 (Pietrzik et al., 2004), APP695 processing may not be significantly influenced by LRP1. Rather than promoting local catabolism of $\mathrm{A} \beta$ in neurons, LRP1, which is expressed in the neurovascular unit and the choroid plexus might also mediate export of $A \beta$ across the $\mathrm{BBB}$ and brain cerebrospinal fluid barrier (BCSFB) (Deane et al., 2004a,b; Zlokovic, 2004). In brain endothelial cells and epithelial cells of the choroid plexus LRP1 may bind directly to A $\beta 1-40$ and export it across the BBB and BCSFB (Deane et al., 2004a,b; Fujiyoshi et al., 2011). In this context, LRP1 and P-glycoprotein (P-gp) have been implicated in A $\beta$ efflux (Shibata et al., 2000; Hartz et al., 2010; Katsouri and Georgopoulos, 2011). LRP-1 is located on the abluminal endothelial cell membrane, whereas $\mathrm{P}$-gp is located on the luminal (blood-facing) surface. The receptor for advanced glycation end products (RAGE), also located on the luminal side of the endothelium, has been linked to $A \beta$ influx (Deane et al., 2003; Sagare et al., 2011a,b).

LRP-1 is also playing other important roles in the central nervous system (Fuentealba et al., 2009, 2010), especially in neurons where it is highly expressed and where it interacts with numerous neuronal proteins such as the postsynaptic density protein 95 (PSD-95) and the N-methyl-D-Aspartate (NMDA) receptor. LRP1 has been found to regulate calcium influx into neurons following stimulation with the glutamate receptor agonist NMDA (Qiu et al., 2002). The molecular mechanism that underlies this effect has not yet been identified. However, the possibility that LRP1 might modulate the functions of neuronal synaptic proteins is in agreement with the results by May et al. (2002); using primary cultured neurons, they showed that LRP1 is present in close proximity to the NMDA receptor in dendritic synapses and can be co precipitated with both NMDA receptor subunits and the postsynaptic density protein PSD-95. Moreover, treatment with NMDA, but not dopamine, reduces the interaction of LRP1 with PSD-95, indicating that LRP1 participates in transmitter-dependent postsynaptic responses, where it would be able to modulate the conductance of neuronal ion channels. Moreover, LRP1 has been shown to regulate calcium signaling in vitro (Bacskai et al., 2000), an important second messenger during glutamate neurotransmission. The active form of $\alpha 2 \mathrm{M}$, an LRP2 ligand, inhibits the calcium-dependent NMDA responses and the expression of NMDA receptors, through a signaling pathway involving LRP1 (Qiu et al., 2002). In fact, mice lacking LRP1 in neurons exhibit a severe mobility disorder, hyperactivity and premature death (May et al., 2004)

An interesting function of LRP1 in neurons is its ability to bind prion protein $(\mathrm{PrP})$ in neurons. Several papers argue that LRP1 controls the surface and biosynthetic trafficking of normal cellular prion protein (PrPC) in neurons. The trafficking of PrPC is believed to control its conversion to the altered conformation (designated PrPSc) associated with prion disease. It was demonstrated that LRP1 is able to associates with PrPC during its endocytosis and is functionally required for this process. Experimentally it was showed that PrPC and LRP1 can be co-immunoprecipitated from the endoplasmic reticulum (ER) in normal neurons. The N-terminal domain of PrPC binds to purified human LRP1 with nanomolar affinity, even in the presence of $1 \mathrm{mM}$ of the LRP-specific chaperone, (RAP) (Taylor and Hooper, 2007).

For infectious prion protein (designated PrPSc) to act as a template and convert normal PrPC to its distinctive pathogenic conformation, the two forms of PrP must interact closely. Interestingly, the neuronal receptor, that rapidly endocytoses the PrPC, is the LRP1. Parkyn et al. (2008) showed here that on sensory neurons LRP1 is also the receptor that binds and rapidly endocytoses smaller oligomeric forms of infectious prion fibrils, and recombinant PrP fibrils. When PrPSc is endocytosed, PrPSc fibrils are routed to lysosomes, rather than recycled to the cell surface with PrPC. Thus, although LRP1 binds both forms of PrP, it traffics them to different destinations within sensory neurons. The binding to ligand cluster 4 should enable genetic modification of PrP binding without disrupting other roles of LRP1 essential to neuronal viability and function, thereby enabling in vivo analysis of the role of this interaction in controlling both prion and LRP1 biology (Parkyn et al., 2008; Jen et al., 2010).

However, the most important function of LRP1 in neurons is the major role in the transport and metabolism of cholesterol associated with ApoE-containing lipoproteins. Cholesterol is an essential component of neuronal membrane and myelin sheaths, and is crucial for synaptic integrity and neuronal function (Pfrieger, 2003). Reduced synthesis and increased need for cholesterol by neurons in adult brains require active cholesterol transport to these cells to support synaptic functions and repair (Bu, 2009). Addition of cholesterol to cultured neurons strongly enhances the number and efficacy of synapses in a ApoE dependent manner (Mauch et al., 2001).

Brain ApoE particles, produced primarily by astrocytes, deliver cholesterol and other lipids to neurons via ApoE receptors (ApoER), which belong to the low-density lipoprotein receptor family (Herz and Bock, 2002; Bu, 2009). ApoE promotes the neuronal uptake of cholesterol via LRP1.

In addition to transporting ligands to the cells, ApoE receptors also mediate cellular signaling by binding a variety of extracellular ligands and intracellular adaptor proteins (Herz and Chen, 2006). The best characterized signaling pathway is triggered by Reelin and mediated by type 2 of ApoER. It is well described that Reelin signaling is crucial for neuronal migration (Trommsdorff et al., 1999), dendritic spine development (Niu et al., 2008) and synaptic plasticity (Beffert et al., 2005).

The association of ApoE with $\mathrm{AD}$ is very well described in the literature. To since 1990's the ApoE was immunochemically localized to the senile plaques, vascular amyloid, and neurofibrillary tangles of $\mathrm{AD}$. The gene for ApoE is located on chromosome 19q13.2, within the region previously associated with late-onset familial AD. Analysis of ApoE alleles in Alzheimer disease and controls demonstrated that there was a highly significant association of ApoE type 4 allele (APOE-epsilon 4) and late-onset 
familial Alzheimer disease. Although biochemical evidence suggests that ApoE interferes with Reelin binding to ApoE receptors (D'Arcangelo et al., 1999), the relationship between the two proteins is still not clear. In neurons, ApoE isoforms differentially affect several signaling cascades through ApoE receptors, including increased phosphorylation of disabled 1 (Dab1), activation of the extracellular signal-regulated kinase $1 / 2$ (ERK1/2) pathway and inhibition of the c-Jun N-terminal kinase $1 / 2$ (JNK1/2) pathway (Hoe et al., 2005). ApoE4, but not ApoE3, significantly increases resting calcium, calcium response to NMDA and neurotoxicity in a LRP1 dependent manner (Qiu et al., 2003). Interestingly, ApoE3/lipoprotein affords greater protection from apoptosis than ApoE4/lipoprotein via LRP1-mediated signaling that involves activation of protein kinase $\mathrm{C} \delta(\mathrm{PKC} \delta)$ and inactivation of glycogen synthase kinase-3 $\beta$ (GSK3 $\beta$ ) (Hayashi et al., 2007). The implication of LRP1 and its ligands in the pathogenesis of $\mathrm{AD}$ is very well described (Vasquez-Higuera et al., 2009).

Several evidences implicated LRP in the pathogenesis of AD. Another interestingly option is the relationship between extracellular matrix and the LRP signaling. Heparan sulphate proteoglycans (HSPGs) are abundant cell surface receptors that interact with a variety of ligands through electrostatic interactions (Poon and Gariepy, 2007). HSPGs found on the surface of almost all mammalian cells are members of the glycosaminoglycan family of polysaccharides and are involved in a large number of biological processes. In neurodegenerative diseases several HSPGs co-localize with senile plaques and cerebral amyloid angiopathy (van Horssen et al., 2003). Heparin and heparan sulphate are able to modify the properties of growth factors activities (Spuch et al., $2004,2006)$, in fact theses proteoglycans are able to bind to $A \beta$ (Brunden et al., 1993) and attenuate neurotoxicity and inflammatory activity of $A \beta$, suggesting a potentially important role for HSPG in cellular metabolism of $A \beta$ (Bergamaschini et al., 2002). In addition, LRP1 and HSPG are part of an immunoprecipitable complex at the cell surface to mediate lipid metabolism (Wilsie and Orlando, 2003). A $\beta$ may initially bind to the HSPG sites on the surface of the complex and then may undergo endocytosis via LRP1, in a process analogous to another LRP1 ligand Internalization of ApoE/lipoprotein particles is partially dependent on the HSPG and LRP1 complex (Mahley and Ji, 1999), suggesting a cooperative function for these ApoE receptors at the neuronal and astrocytes cell surface (Kanekiyo et al., 2011).

\section{Intracellular domain (ICD)}

LRP-1 has also been shown to interact with scaffolding and signaling proteins via its intracellular domain in a phosphorylationdependent manner and to function as a co-receptor partnering with other cell surface or integral membrane proteins. LRP-1 is thus implicated in two major physiological processes: endocytosis and regulation of signaling pathways, which are both involved in diverse biological roles including lipid metabolism, cell growth/differentiation processes, degradation of proteases, and tissue invasion. The embryonic lethal phenotype obtained after target disruption of the LRP-1 gene in the mouse highlights the biological importance of this receptor and revealed a critical, but yet undefined role in development. Tissue-specific gene deletion studies also reveal an important contribution of LRP1 in the central nervous system, in vascular remodeling (especially brain vascular endothelium), foam cell biology, and also in the molecular mechanisms of atherosclerosis.

As the case for numerous receptor and membrane proteins, the extracellular domain (ECD) of LRP1 can be cleaved by cell surface proteases and subsequently released into extracellular space or the circulation (plasma or CSF) (Zlokovic, 2011). This cleaved form of LRP1 contains the $\alpha$-chain of about $515 \mathrm{kDa}$ and a fragment of $\beta$-chain of about $55 \mathrm{kDa}$, demonstrating that the cleavage occurs close to the plasma membrane (May et al., 2003). Enzymes that can mediated this cleavage include the neuronal BACE1 (von Einem et al., 2010) and metalloproteinase (Selvais et al., 2011). The physiological mean of LRP1 soluble form is not certain, but since the soluble form can still bind most of the LRP1 ligands and thereby reduce their endocytoses by cellular LRP1, the soluble fragment may serve to quench extracellular ligand interaction with cell or regulate their intracellular trafficking. Zlokovic's group has identified the LRP1 such as a major $\mathrm{A} \beta$-binding protein in plasma. This soluble receptor may bind $70-90 \%$ of the $\mathrm{A} \beta$ that circulates in peripheral blood and seems to function as a peripheral sink for Alzheimer's disease causing brain $A \beta$. Using a mouse model of Alzheimer's disease, the authors demonstrated that boosting the capacity of the sink by administering a form of soluble LRP1, reduces brain amyloid plaque load and improves learning and memory. They extend these results by demonstrating that patients with $\mathrm{AD}$ have depressed plasma soluble LRP1 levels.

There is growing evidence that proteolytic degradation of membrane spanning regulatory proteins is involved in a variety of important trans-membrane signaling processes. This mechanism of regulated intramembrane proteolysis (RIP) enables them to respond to extracellular signals. $\gamma$-secretase may play a central role in a signaling paradigm that has been termed RIP. RIP processing is described in different receptors such as p75NTR, ErbB4, APP, Notch and also LRP1 and LRP2, by allowing ICD to translocate to the nucleus (Hass et al., 2009; Spuch and Navarro, 2010a,b; Spuch and Carro, 2011; Groot and Vooijs, 2012). Alternatively, RIP may turn off signaling events in which the transmembrane anchored protein is responsible for signaling and cleavage terminates the signal.

An extremely important point in regards to RIP, largely ignored by most investigators, is that the fate of any ICD is dependent on its $\mathrm{N}$-terminus that dictates the stability of the cleaved products. According to the N-end rule, only ICDs whose $\mathrm{N}$-terminus evades ubiquitination escape degradation, whereas fragments beginning in other residues undergo rapid proteasomal degradation (Tasaki and Kwon, 2007).

This potential mechanism in LRP1 regulation involves the cleavage of the transmembrane domain of the LRP1 $\beta$-chain by RIP. The released fragment (LRP1-ICD) of $12 \mathrm{kDa}$ might thus translocate to the nucleus where it can regulate the transcription of target genes (Derocq et al., 2012). LRP1 following PKC activation and metalloproteinase-induced shedding of the (ECD), the LRP1-ICD is released from the membrane by $\gamma$-secretase. This cytoplasmic fragment may have functions in the cytoplasm or in 
the nucleus, including transcriptional regulation. Although the LRP1-ICD functions are still unknown, recently, one potential target of the LRP1-ICD has been identified. Lipopolysaccharide (LPS) increases the proteolytic processing of the ectodomain of LRP1, which results in the $\gamma$-secretase-dependent release of the LRP1-ICD from the plasma membrane and its subsequent translocation to the nucleus, where it interacts with and represses the interferon- $\gamma$ promoter (Zurhove et al., 2008).

The LRP1-ICD fragment contains numerous motifs that have been implicated in numerous signaling pathways: Two NPXY motifs, where the distal motif is contiguous with a YXXL motif, and two dileucine motifs. The YXXL motif is presumably the most important one mediating LRP1 endocytosis (Li et al., 2000). However, both NPXY motifs can bind and interact with numerous cytosolic proteins such as, DAB1, FE65, JIP1, PSD-95, ShcA or CED-6/GULP (Berger et al., 2010; Boucher and Herz, 2011). In vitro studies have shown that the LRP1-ICD can colocalize with the histone acetyl transferase Tip60 in the nucleus (Kinoshita et al., 2003), which in turn can regulate transcription upon APP cleavage (Baek et al., 2002) suggesting that the LRP1-ICD might be able to regulate the transcriptional activity of the APP-Tip60 complex, and thus have a more general function as a regulator of transcription.

\section{LOW DENSITY LIPOPROTEIN RECEPTOR-RELATED PROTEIN-2 (LRP2)}

LRP2, also called megalin, is one of the largest cell surface glycoproteins present in vertebrates, is a transmembrane protein with a non-glycosytaled molecular weigh of $517 \mathrm{kDa}$ (Saito et al., 1994; Chowdhary et al., 1995; Spuch and Navarro, 2010a,b). This receptor is structurally very similar to LRP1. LRP2 is composed of a large ECD consisting of four cysteine-rich complement-type ligand binding repeats, responsible for ligand binding (Table 1), that binds to the chaperone RAP (receptor associated protein) for its folding in the (ER) (Bu and Marzolo, 2000). The repeats are separated from each other by $\beta$-propeller domains (Saito et al., 1994), structured by repeats of YWTD flanked by EGF-like modules, that are generally important for the proper receptor folding in this family of proteins (Culi et al., 2004; Lighthouse et al., 2010) as well as for the dissociation of their ligands in the acidic endosomal compartment (Jeon et al., 2001). In addition, LRP2 contains one transmembrane domain that targets it to membrane domains rich in cholesterol and glycosphingolipids (Marzolo et al., 2003) and is also a substrate for the $\gamma$-secretase complex (Zou et al., 2004). Among these are three NPXY motifs that have been linked to LDLR and LRP1 internalization mediated by clathrin, recycling from the endosomal compartment to the plasma membrane and basolateral distribution (Donoso et al., 2009). However, the roles of these motifs have not been clearly defined for LRP2 (Figure 2).

\section{LRP2 expression in the brain}

In the healthy brain, the expression of LRP-2 is classically published in ependymal cells lining the ventricular wall, capillaries and choroid plexus (Zheng et al., 1994; Chun et al., 1999; Carro et al., 2005). The expression is principally restricted to epithelial cells, specifically at the apical surface (Willnow, 1999). Interestingly, despite the presence of some putative basolateral sorting motifs in the cytoplasmic domain of LRP2, its apical localization depends mainly on sorting information present in this domain of the receptor because its addition to a reporter protein that lacks sorting information drives trafficking of the reporter to the apical surface of polarized epithelial cells (Marzolo et al., 2003) However, during the last years several papers were published describing the expression of LRP2 within peripheral and central nervous system. The first evidences for LRP2 localization in the central nervous system were described through developmental studies. It is well known that genetic deficiency of LRP-2 or inactivation of the lrp2 gene leads to holoprosencephalic phenotype, characterized by abnormal development of the forebrain, absence of olfactory apparatus and cranio-facial malformations (Assemat et al., 2005). A novel mutation in $\operatorname{lrp} 2$ gene that causes an enlarged cortex, abnormalities in the dorsal diencephalon further hypertrophy of the choroid plexus of the third ventricle was also identified (Zarbalis et al., 2004).

Within the central nervous system, further ependyma of the choroid plexus (Spuch and Navarro, 2010a,b), LRP-2 is widely expressed on neurons (LaFerla et al., 1997) and astrocytes (BentoAbreu et al., 2008). In astrocytes this receptor is required for albumin binding and internalization into astrocytes inducing synthesis of neurotrophic factors by the neighbouring neurons (Bento-Abreu et al., 2009). Other observations identified that LRP-2 is present in retinal ganglion cells and in astrocytic processes of young and adult rats. In these cells, LRP-2 interacted with metallothionein-IIA allowing the activation of different intracellular signaling pathways involved in neuroprotection (Fitzgerald et al., 2007). In this context, studying the role of metallothionein as a neuroprotective factor and ligand of LRP-2, it was described the expression of LRP-2 in cerebellar granule cells being mediator of the neuroprotective action of metallothionein (Ambjorn et al., 2008). Due to the growing evidence that LRP-2 expression in the brain is not restricted to tight-junction epithelia, oligodendrocytes and glial cells, our group recently published the broad expression of this endocytic receptor in different neuronal populations of the brain. In brain samples from healthy humans, monkeys, pigs, mice and rats we demonstrated LRP2 localization in different neuronal populations from cerebral cortex, hippocampus, striatum, thalamus, olfactory bulb and cerebellum (Alvira-Botero et al., 2010). Interestingly, in brain tissues from patients diagnosed with Alzheimer's disease, LRP-2 expression has been immunohistochemically detected in neurons, even being up regulated in damaged neurons (LaFerla et al., 1997).

\section{LRP2 and signal transduction in the brain}

LRP2 is an endocytic receptor which binds its extracellular ligands before an endocytic uptake. The activation of different signaling pathways is due to LRP2 dependent internalization of a number of ligands representing a wide variety of molecules, including lipoproteins, hormones, vitamin-binding proteins and drugs (Table 1). The signaling functions in the cytoplasm are controlled by their interaction with adaptor proteins that recognize specific motifs within the cytoplasmic domains of LRP-2. There are evidences linking LRP2 endocytosis to non-clathrin mediated pathways involving trafficking proteins such as the small GTPase Arf6 (Wolff et al., 2008) and caveolin 1 (Bento-Abreu et al., 2009). Two cytoplasmic proline-rich sequences and a PDZ-binding motif 


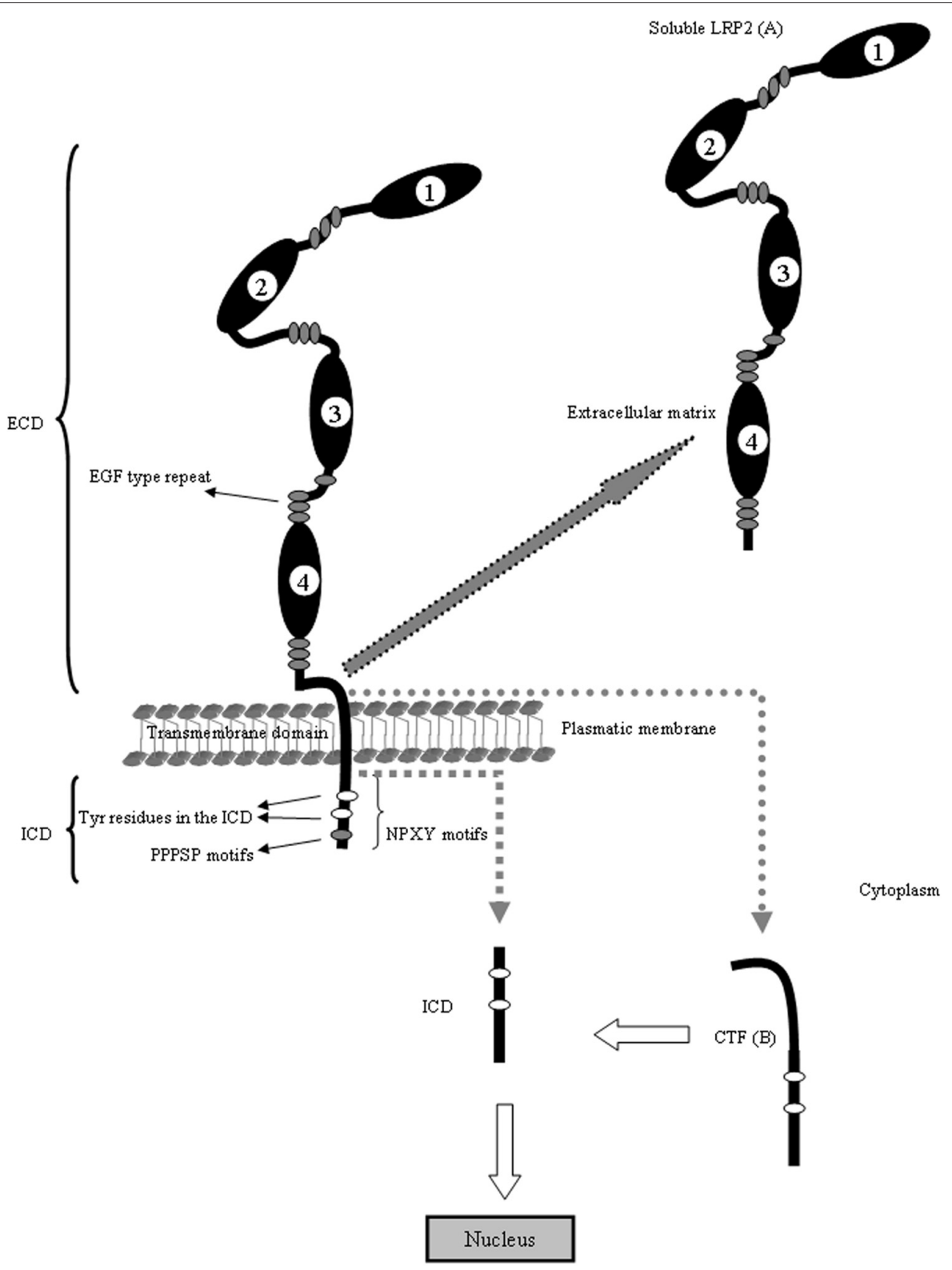

FIGURE 2 | LRP2 is structurally similar to LRP1. The ECD of LRP2 contains four clusters (1-4) of lipoprotein receptor ligand-binding repeats, growth factor repeats, an EGF repeat, and YWTD spacer regions. Interestingly, the second cluster has been identified as a common binding site for several ligands including Apo E, Apo M, retinol binding protein and transthyretin. The fourth cluster has been identified as binding site for A 3 . The LRP2 is also proteolytically cleaved to generate two subunits: (A) the $\mathrm{N}$-terminal (soluble LRP2) containing the ligand-binding domains and (B) the C-terminal subunit containing an extracellular fragment (CTF), the transmembrane spanning domain and the ICD. The ICD contains diverse potential endocytosis and signaling motifs. The ICD binds adaptor proteins important for LRP2-mediated endocytoses, such as Dab2 and is able to induce intracellular events such as
RIP signaling. The cytoplasmic domain of LRP2 has several putative internalization motifs, including one dileucine and three NPXY motifs. In addition, it contains two proline-rich sequences, one PDZ terminal motif, several putative protein kinase $\mathrm{C}$ and casein kinase II phosphorylation motifs as well as one protein kinase A phosphorylation motif. Under basal conditions, these motifs contribute little to the phosphorylation of the LRP2 cytoplasmic domain. Although there are few evidences about the cytoplasmic regulation of LRP1 and LRP2, the mechanism is conserved in the gene evolution and probably the regulation and trafficking of both receptors in neurons are very similar. With arrows is indicating the cleavage events in the molecule and the resulting fragments. have been implicated in the direct and indirect interaction of LRP2 with cytoskeletal and cytosolic scaffold and signaling proteins, such as GIPC/ synectin, megalin-binding protein, ANKRA, myosin VI, SKIP, Disabled 2 (Dab2) and APPL1 (Rader et al.,
2000; Patrie et al., 2001; Larsson et al., 2003; Spuch and Navarro, 2010a,b). An interesting feature of LRP2 is that it is constitutively phosphorylated by GSK3 at a PPPSP motif, contained in a distal proline-rich motif of the cytoplasmic tail. This PPPSP 
motif is the most significant in terms of basal phosphorylation of the receptor, despite the presence of several other consensus phosphorylation sites for PKC, CK-II and PKA and its function is related to the control of LRP2 recycling from the endosomes (Yuseff et al., 2007).

Recent data identify a critical role for LRP2 in SHH signaling and reveal the molecular mechanism underlying forebrain anomalies in mice and patients with $\operatorname{Lrp} 2$ defects. This group identified LRP2 as a component of the SHH signaling machinery in the rostral diencephalon ventral midline. LRP2 is acting as an apical SHH-binding protein that sequesters $\mathrm{SHH}$ in its target field and controls internalization and cellular trafficking of SHH/patched 1 complexes (Christ et al., 2012).

In the brain, LRP2 participates in endocytosis and internalization of ApoE, APP and A $\beta$ peptide (LaFerla et al., 1997). The first signaling event described for LRP2 was suggested by Strickland's group showing that LRP2 is responsible for solubleAPP endocytosis (Kounnas et al., 2008). Recently, our group published in cortical and hippocampal neurons that LRP2 is able to form a macromolecular complex together with APP and Fe65 acting as a negative regulator of neurite branching and as mediator of $\mathrm{A} \beta$ neurotoxicity (Alvira-Botero et al., 2010). In another study with granule cells from cerebellum described as metallothionein induced neuronal differentiation, survival and initiate signal transduction pathways resulting in neurite outgrowth by binding of LRP2 (Ambjorn et al., 2008). In spite of the poor information available it seems that the activation of LRP2 upon ligand binding mediates neurite outgrowth and apoptosis.

Also, it was demonstrated that LRP2, a receptor implicated in BMP4 clearance is specifically expressed in ependymal cells of the lateral ventricles in the adult brain. Intriguingly, expression is restricted to the ependyma that faces the stem cell niche. Expression is not seen in ependyma elsewhere in the lateral ventricles or in the dentate gyrus, the second major neurogenic zone of the adult brain. This group further showed that lack of LRP2 expression in adult mice results in impaired proliferation of neural precursor cells in the subependymal zone resulting in decreased numbers of neuroblasts reaching the olfactory bulb. Reduced neurogenesis coincides with increased BMP4 expression and enhanced activation of downstream mediators phosphoSMAD1/5/8 and ID3 in the stem cell niche. These findings suggest a novel mechanism whereby LRP2-mediated catabolism of BMP4 in the ependyma modulates the microenvironment of the subependymal zone and enables adult neurogenesis to proceed (Gajera et al., 2010).

\section{Intracellular domain}

Similarly to what described for LRP1, LRP2 is also able to initiate signaling events related with RIP processing in a manner similar to that described for APP and Notch. This receptor undergoes proteolytic shedding of the ECD by a metalloproteinase. It has recently been shown that the cytoplasmic tail of LRP-2 can be processed intramembranously by a $\gamma$-secretase activity that releases its ICD-LRP2 (Biemesderfer, 2006). Following the RIP processing in the cytoplasmic domain of LRP2, this receptor also undergoes proteolytic shedding of the ECD by a metalloproteinase, generating truncated forms, also named soluble-LRP2, corresponding with the 4-loop of LRP-2 (Ishida et al., 2006). The $\mathrm{COOH}$-terminal fragment is in turn released from the membrane by $\gamma$-secretase activity acting at a cleavage site within the proteins membrane spanning domain. Once released, the $\mathrm{COOH}$-terminal domain traffics to the nucleus where, through interaction with transcription factors, it controls expression of target genes (Ebinu and Yankner, 2002). However, related to $\mathrm{COOH}$ fragment of LRP-2 nothing is known about its regulation in neurons. Our group found LRP2-ICD in rat hippocampal neurons in vitro (unpublished data). Furthermore, the function of these events in the context of the brain is completely unknown. We suggest that LRP2-ICD could be regulated by LRP2 ligands and may be involved in gene transcriptions and apoptosis events, although more investigations are necessary to discover relevant facts about LRP2-ICD in neurons. The unique evidence about the function of LRP2-ICD was described in kidney, where it seems likely that RIP of LRP-2 is part of a more complex molecular pathway that ensures LRP2 expression at some necessary physiologic level ( $\mathrm{Li}$ et al., 2008).

\section{LRP-1/LRP-2 ROLES IN AD}

Advancing age is a major risk factor for many neurodegenerative disorders, and the major risk factor for $\mathrm{AD}$, a disease characterized by progressive memory and cognitive loss (Selkoe et al., 2012). The most accepted hypothesis for the mechanism of brain injury in $\mathrm{AD}$ is the "amyloid cascade," comprising amyloid accumulation in the brain, the formation of toxic oligomeric and intermediate forms of $A \beta$ peptides, amyloid plaques, inflammation and the induction of neurofibrillary tangles (Jin et al., 2011). There is accumulation of $A \beta$ in both, the normal aging brain and the $\mathrm{AD}$ brain, thought to be related to defective $\mathrm{A} \beta$ clearance rather than increased $A \beta$ production (Zlokovic et al., 2010). This has recently been shown to be the case in AD. Clearance of this peptide from the brain occurs via active transport at the interfaces separating the central nervous system from the peripheral circulation. Through the BBB and the BCSFB, LRP1 and LRP2, facilitate the clearance of the $A \beta$ peptide that is produced by amyloidogenic processing of the APP, which can form complexes with different LRPs ligands such as ApoJ (also called clusterin) and ApoE (Zlokovic, 2004, 2011; Nuutinen et al., 2009) and ApoE. In addition to these ligands, a neuroprotective role for the $A \beta$ binding protein called gelsolin (Carro, 2010), that is produced and secreted in the epithelial cells of the choroid plexus (Vargas et al., 2010a), was recently demonstrated. Gelsolin has neuroprotective functions in controlling the $\mathrm{A} \beta$-induced production of $\mathrm{NO}$ and apoptosis as well as cytoskeletal disruptions in the epithelial cells of the cerebrospinal fluid barrier (Vargas et al., 2010a).

Several lines of evidence have implicated LRP and LRP ligands in the pathogenesis of Alzheimer's disease (Nieoullon, 2011). First, LRP is a major neuronal receptor for ApoE/lipoprotein, and the epsilllon 4 allele of ApoE is a strong genetic risk factor for lateonset AD. LRP-mediated brain metabolism of ApoE/lipoprotein can also influence the metabolism of cholesterol, which has been suggested to contribute to the pathogenesis of $\mathrm{AD}$ by regulating $A \beta$ metabolism. Second, immunoreactive staining of several LRP ligands (e.g., ApoE, $\alpha 2 \mathrm{M}$, and tissue factor pathway inhibitor) as well as LRP itself has been detected in senile plaques. 
Third, some genetics studies have suggested that LRP1 and LRP2 are linked to $\mathrm{AD}$ and cerebral amyloid angiopathy (Ballatore et al., 2007). Two recent genome-wide association studies have reported that PICALM (phosphatidylinositol binding clathrin assembly protein) and ApoJ (also known as clusterin) are the only two $\mathrm{AD}$ susceptibility genes (Harold et al., 2009). However, this year it was published a study where the 10 most promising late-onset $\mathrm{AD}$ susceptibility genes identified through several recent large GWAS (APOE, CLU, PICALM, CR1, BIN1, ABCA7, MS4A6A, CD33, CD2AP, and EPHA1). This study has been identified curiously, apart from the APOE locus which showed compelling evidence of association with risk on human life span, none of the other gene loci demonstrated significant evidence of association (Shi et al., 2012). However, last studies of Carro's group demonstrated three new polymorphisms in the genes PLA2G3, IGF-I and LRP2 associated with $\mathrm{AD}$ in a Spanish population (Martínez-García et al., 2010; Vargas et al., 2010b, 2011).

Together these observations indicate that LRP can participate in $\mathrm{AD}$ pathogenesis by altering the catabolism of LRP ligands (e.g., IGF-I, ApoE/lipoprotein/cholesterol, tPA, and $\alpha 2 \mathrm{M}$ ) and/or influencing $\mathrm{A} \beta$ metabolism and accumulation (Carro et al., 2002, 2005, 2006). Further, it has been shown that the LRP1 and LRP2 cytoplasmic C-terminal domain interact with APP cytoplasmic domain via FE65, which in turn influences APP processing and $\mathrm{A} \beta$ generation (Pietrzik et al., 2004; Alvira-Botero et al., 2010).

Recent findings have revealed the roles of $\gamma$-secretase and LRP1 in the inhibition of the inflammatory response suggesting that both proteins may serve as potential therapeutic targets for the modulation of inflammation (Zurhove et al., 2008). Furthermore, none is known about the speculative effect of LRP2 in the

\section{REFERENCES}

Alvira-Botero, X., Perez-Gonzalez, R., Spuch, C., Vargas, T., Antequera, D., Garzon, M., Bermejo-Pareja, F., and Carro, E. (2010). Megalin interacts with APP and the intracellular adaptor protein Fe65 in neurons. Mol. Cell. Neurosci. 45, 306-315.

Ambjorn, M., Asmussen, J. W., Lindstam, M., Gotfryd, K., Jacobsen, C., Kiselyov, V. V., Moestrup, S., Penkova, M., Bock, E., and Berezin, V. (2008). Metallothionein and a peptide modelled after metallothionein, Emtin, B, induced neuronal differentiation and survival through binding to receptors of the lowdensity lipoprotein receptor family. J. Neurochem. 104, 21-37.

Ananyeva, N. M., Makogonenko, Y. M., Sarafanov, A. G., Pechik, I. V., Gorlatova, N., Radtke, K. P., Shima, M., and Saenko, E. L. (2008). Inteaction of coagulation factor VIII with members of the low-density lipoprotein receptor family follows common mechanism and involves consensus residues within the $\mathrm{A} 2$ binding site 484-509. Blood Coagul. Fibrinolysis 19, 543-555.

Andersen, O. M., and Willnow, T. E. (2006). Lipoprotein receptors in Alzheimer's disease. Trends Neurosci. 29, 687-694.

Assemat, E., Chatelet, F., Chandellier, J., Commo, F., Cases, O., Verroust, P., and Kozyraki, R. (2005). Overlapping expression patterns of the multiligand endocyte receptors cubilin and megalin in the CNS, sensory organs and developing epithelia of the rodent embryo. Gene Expr. Patterns 6, 69-78.

Bacskai, B. J., Xia, M. Q., Strickland, D. K., Rebeck, G. W., and Hyman, B. T. (2000). The endocitic receptor protein LRP also mediates neuronal calcium signalling via $\mathrm{N}$-methyl-Daspartate receptors. Proc. Natl. Acad. Sci. U.S.A. 97, 11551-11556.

Baek, S. H., Ohgi, K. A., Rose, D. W., Koo, E. H., Glass, C. K., and Rosenfeld, M. G. (2002). Exchange of N-CoR corepressor and Tip60 coactivator complexes links gene expression by NF-kappaB and betaamyloid precursor protein. Cell 110, 55-67. neuroinflammation. Probably, the modulation of LRP1 and LRP2 in the different cells of the neurovascular unit could be new therapeutic strategy.

\section{CONCLUSIONS}

In summary, we have reviewed recent evidence suggesting that LRP1 and LRP2 have a major role in regulating brain and systemic clearance of $A^{\beta}$. Since the discovery of both LRPs as important endocytic receptors present in the brain endothelium and epithelial cells of the choroid plexus several new ligands and functions for these proteins have been uncovered. Recent findings in LRPs functions in the brain cells (astrocytes, glial cells and neurons) and their role in the internalization of different molecules, open the possibility that these receptors can be used as a target and regulator of signal transduction pathways, as well as the emergence of its roles in neurodegeneration and regeneration processes and in chronic and genetic diseases. The modulation of LRP1 and LRP2 in the different cells of the neurovascular unit could be new strategy therapeutic. However, as a note of caution, the development of LRPs-based therapies for neurodegenerative diseases requires careful toxicity and safety monitoring of unwanted potential side effects given that LRPs participate in multiple control systems in the body (cellular transport in different organs, anticoagulation process and inflammation).

\section{ACKNOWLEDGMENTS}

We thank Tania Vazquez for editorial assistance. This work was supported by grants from Xunta de Galicia (INCITE2009, 09CSA051905PR), Instituto Carlos Carlos III, Accion Estratégica en Salud (PI11/00842) and "Isidro Parga Pondal" programme.
Ballatore, C., Lee, V. M., and Trojanowski, J. Q. (2007). Tau mediated neurodegeneration in Alzheimer's disease and related disorders. Nat. Rev. Neurosci. 8 , 663-672.

Beffert, U., Weeber, E. J., Durudas, A., Qiu, S., Masilius, I., Sweatt, J. D., Li, W. P., Adelaman, G., Frotscher, M., Hammer, R. E., and Herz, J. (2005). Modulation of synaptic plasticity and memory by Reelin involves differential splicing of the lipoprotein receptor Apoer2. Neuron 47, 567-579.

Bento-Abreu, A., Velasco, A., PóloHernandez, E., Lillo, C., Kozyraki, R., Tabernero, A., and Medina, J. M. (2009). Albumin endocytosis via megalin in astrocytes is caveola- and Dab-1 dependent and is required for the synthesis of the neurotrophic factor oleic acid. J. Neurochem. 111, 49-60.

Bento-Abreu, A., Velasco, A., PóloHernandez, E., Perez-Reyes, P. L., Tabernero, A., and Medina, J. M. (2008). Megalin is a receptor for albumin in astrocytes and is required for the synthesis of the neurotrophic factor oleic acid. $J$ Neurochem. 106, 1149-1159.

Bergamaschini, L., Donarini, C., Rossi, E., De Luigi, A., Vergani, C., and De Simoni, M. G. (2002). Heparin attenuates cytotoxic and inflammatory activity of Alzheimer amyloidbeta in vitro. Neurobiol. Aging 23, 531-536.

Berger, Z., Smith, K. A., and Lavoie, M. J. (2010). Membrane localization of LRRK2 is associated with increased formation of the highly active LRRK2 dimer and changes in its phosphorylation. Biochemistry 49, 5511-5523.

Biemesderfer, D. (2006). Regulated intramembrane proteolysis of megalin: linking urinary protein and gene regulation in proximal tubule. Kidney Int. 69, 1717-1721.

Birn, H., Vorum, H., Verroust, P. J., Moestrup, S. K., and Christensen, E. I. (2000). Receptor associated protein is important for normal processing of megalin in kidney proximal tubules. J. Am. Soc. Nephrol. 11, 191-202.

Birn, H., Zhai, X., Holm, J., Hansen, S. I., Jacobsen, C., Christensen, E. I., 
and Moestrup, S. K. (2005). Megalin binds and mediates cellular internalization of folate binding protein. FEBS J. 272, 4423-4430.

Boucher, P., and Herz, J. (2011). Signaling through LRP1, protection from atherosclerosis and beyond. Biochem. Pharmacol. 81, 1-5.

Brandes, C., Novak, S., Stockinger, W., Herz, J., Schneider, W. J., and Nimpf, J. (1997). Avian and murine LR8B and human apolipoprotein E receptor 2, differentially spliced products from corresponding genes. Genomics 42, 185-191.

Brown, M. D., Banker, G. A., Hussaini, I. M., Gonias, S. L., and VandenBerg, S. R. (1997). Low density lipoprotein receptor-related protein is expressed early and becomes restricted to a somatodendritic domain during neuronal differentiation in culture. Brain Res. 747, 313-317.

Brown, S. D., Twells, R. C., Hey, P. J., Cox, R. D., Levy, E. R., Soderman, A. R., Metzker, M. L., Caskey, C. T., Todd, J. A., and Hess, J. F. (1998). Isolation and characterization of LRP6, a novel member of the low density lipoprotein receptor gene family. Biochem. Biophys. Res. Commun. 248, 879-888.

Brunden, K. R., Richter-Cook, N. J., Chaturvedi, N., and Frederickson, R. C. (1993). pH-dependent binding of synthetic beta-amyloid peptides to glycosaminoglycans. J. Neurochem. 61, 2147-2154.

Bruno, E., Quattrocchi, G., Nicoletti, A., Le Pira, F., Maci, T., Mostile, G., Andreoli, V., Quattrone, A., and Zappia, M. (2010). Lack of interaction between LRP1 and A2M polymorphisms for the risk of Alzheimer disease. Neurosci. Lett. 482, 112-116.

Bu, G. (2009). Apolipoprotein E and its receptors in Alzheimer's disease: pathways, pathogenesis and therapy. Nat. Rev. Neurosci. 10, 333-344.

Bu, G., and Marzolo, M. P. (2000). Role of rap in the biogenesis of lipoprotein receptors. Trends Cardiovasc. Med. 10, 148-155.

Carro, E. (2010). Gelsolin as therapeutic target in Alzheimer's disease. Expert Opin. Ther. Targets 14, 585-592.

Carro, E., Spuch, C., Trejo, J. L., Antequera, D., and Torres-Aleman, I. (2005). Choroid plexus megalin is involved in neuroprotection by serum insulin-like growth factor I. J. Neurosci. 25, 10884-10893.

Carro, E., Trejo, J. L., Gomez-Isla, T., LeRoith, D., and Torres-Aleman, I. (2002). Serum insulin like growth factor I regulates brain amyloid beta levels. Nat. Med. 8, 1390-1397.

Carro, E., Trejo, J. L., Spuch, C., Bohl, D., Heard, J. M., and TorresAleman, I. (2006). Blockade of the insulin like growth factor I receptor in the choroid plexus originates Alzheimer's-like neuropathology in rodents: new cues into the human disease? Neurobiol. Aging 27, 1618-1631.

Chan, W. L., Shaw, P. C., Tam, S. C., Jacobsen, C., Gliemann, J., and Nielsen, M. S. (2000). Trichosanthin interacts with and enters cells via LDL receptor family members. Biochem. Biophys. Res. Commun. 270, 453-457.

Chowdhary, B. P., Lundgren, S., Johanson, M., Hjälm, G., Akertsröm, G., Gustavsson, I., and Rask, L. (1995). In situ hybridization mapping of a 500$\mathrm{kDa}$ calcium-sensing protein gene (LRP2) to human chromosome region $2 \mathrm{q} 31->\mathrm{q} 32.1$ and porcine chromosome region $15 \mathrm{q} 22>\mathrm{q} 24$. Cytogenet. Cell. Genet. 71, 120-123.

Christ, A., Christa, A., Kur, E. Lioubinski, O., Bachmann, S., Willnow, T. E., and Hammes, A. (2012). LRP2 is an auxiliary SHH receptor required to condition the forebrain ventral midline for inductive signals. Dev. Cell 22, 268-278.

Christensen, E. I., and Nielsen, R. (2007). Role of megalin and cubilin in renal physiology and pathophysiology. Rev. Physiol. Biochem. Pharmacol. 158, 1-22.

Chun, J. T., Wang, L., Pasinetti, G. M., Finch, C. E., and Zlokovic, B. V. (1999). Glycoprotein 330/megalin (LRP-2) has low prevalence as mRNA and protein in brain microvessels and choroid plexus. Exp. Neurol. 157, 194-201.

Croy, J. E., Shin, W. D., Knauer, M. F., Knauer, D. J., and Komives, E. A. (2003). All three LDL receptors homology regions of the LDL receptor-related protein bind multiple ligands. Biochemistry 42, 13049-13057.

Cui, S., Verroust, P. J., Moestrup, S. K., and Christensen, E. I. (1996). Megalin/gp330 mediates uptake of albumin in renal proximal tubule. Am. J. Physiol. 271, 900-907.

Culi, J., Springer, T. A., and Mann, R. S. (2004). Boca-dependent maturation of beta-propeller/EGF modules in low-density lipoprotein receptor proteins. EMBO J. 23, 1372-1380.

D’Arcangelo, G., Homayouni, R., Keshvara, L., Rice, D. S., Sheldon, M., and Curran, T. (1999). Reelin is a ligand for lipoprotein receptors. Neuron 24, 471-479.

Deane, R., Du Yan, S., Submamaryan, R. K., LaRue, B., Jovanovic, S., Hogg, E., Welch, D., Manness, L., Lin, C., Yu, J., Zhu, H., Ghiso, J., Frangione, B., Stern, A., Schmidt, A. M., Armstrong, D. L., Arnold, B., Liliensiek, B., Nawroth, P., Hofman, F., Kindy, M., Stern, D. and Zlokovic, B. (2003). RAGE mediates amyloid-beta peptide transport across the blood-brain barrier and accumulation in brain. Nat. Med. 9, 907-913.

Deane, R., Sagare, A., Hamm, K., Parisi, M., Lane, S., Finn, M. B., Holtzman, D. M., and Zlokovic, B. V. (2008). apoE isoform specific disruption of amyloid beta peptide clearance from mouse brain. J. Clin. Invest. 118 , 4002-4013.

Deane, R., Wu, Z., and Zlokovic, B. V. (2004a). RAGE (yin) versus LRP (yang) balance regulates alzheimer amyloid beta-peptide clearance through transport across the blood-brain barrier. Stroke 35, 2628-2631.

Deane, R., Wu, Z., Sagare, A., Davis, J., Du Yan, S., Hamm, K., Xu, F., Parisi, M., LaRue, B., Hu, H. W. Spijkers, P., Guo, H., Song, X., Lenting, P. J., Van Nostrand, W. E., and Zlokovic, B. V. (2004b). LRP/amyloid $\beta$-peptide interaction mediates differential brain efflux of $\mathrm{A} \beta$ isoforms. Neuron 43, 333-344.

Demeule, M., Currie, J. C., Bertrand, Y., Ché, C., Nguyen, T., Régina, A., Gabathuler, R., Castaigne, J. P., and Béliveau, R. (2008). Involvement of the low-density lipoprotein receptor-related protein in the transcytosis of the brain delivery vector Angiopep-2. J. Neurochem. 106, 1534-1544.

Derocq, D., Prébois, C., Beaujouin, M., Laurent-Matha, V., Pattingre, S., Smith, G. K., and LiaudetCoopman, E. (2012). Cathepsin D is partly endocytosed by the LRP1 receptor and inhibits LRP1 regulated intramembrane proteolysis. Oncogene 31, 3202-3212.

Dietrich, M. O., Spuch, C., Antequera, D., Rodal, I., de Yébenes, J. G. Molina, J. A., Bermejo, F., and Carro, E. (2008). Megalin mediates the transport of leptin across the blood-CSF barrier. Neurobiol. Aging 29, 902-912.

Donoso, M., Cancino, J., Lee, J., Van Herkhof, P., Retamal, C., Bu, G., Gonzalez, A., Caceres, A., and Marzolo, M. P. (2009). Polarized traffic of LRP1 involves AP1B and SNX17 operating on Y-dependent sorting motifs in different pathways. Mol. Biol. Cell 20, 481-497.

Ebinu, J. O., and Yankner, B. A. (2002). A RIP tide in neuronal signal transduction. Neuron 34, 499-502.

Faber, K., Hvidberg, V., Moestrup, S. K., Dahlback, B., and Nielsen, L. B. (2006). Megalin is a receptor for apolipoprotein $\mathrm{M}$, and kidneyspecific megalin-deficiency confers urinary excretion of apolipoprotein M. Mol. Endocrinol. 20, 212-218.

Fester, L., Zhou, L., Bütow, A., Huber, C., von Lossow, R., Prange-Kiel, J., Jarry, H., and Rune, G. M. (2009). Cholesterol promoted synaptogenesis requires the conversion of cholesterol to estradiol in the hippocampus. Hippocampus 19, 692-705.

Fitzgerald, M., Nairn, P., Bartlett, C. A., Chung, R. S., West, A. K., and Beazley, L. D. (2007). Metallothionein-IIA promotes neurite growth via the megalin receptor. Exp. Brain Res. 183, 171-180.

Fuentealba, R. A., Liu, Q., Kanekiyo, T., Zhang, J., and Bu, G. (2009). Low density lipoprotein receptor-related protein 1 promotes anti-apoptotic signaling in neurons by activating Akt survival pathway. J. Biol. Chem. 284, 34045-34053.

Fuentealba, R. A., Liu, Q., Zhang, J., Kanekiyo, T., Hu, X., Lee, J. M., LaDu, M. J., and Bu, G. (2010). Low-density lipoprotein receptorrelated protein 1 (LRP1) mediates neuronal Abeta42 uptake and lysosomal trafficking. PLOS ONE 5:e11884. doi: 10.1371/journal. pone.0011884

Fujiyoshi, M., Tachikawa, M., Ohtsuki, S., Ito, S., Uchida, Y., Akanuma, S., Kamiie, J., Hashimoto, T., Hosoya, K., Iwatsubo, T., and Terasaki, T. (2011). Amyloid-beta peptide (1-40) elimination from cerebrospinal fluid involves low density lipoprotein receptor related protein 1 at the blood cerebrospinal fluid barrier. J. Neurochem. 118, 407-415. Gajera, C. R., Emich, H., Lioubinski, O., Christ, A., Bechervordersandforth-Bonk, R., Yoshikawa, K., Bachmann, S., Christensen, E. I., Gotz, M., Kempermann, G., Peterson, A. S., Willnow, T. E., and Hammes, A. (2010). LRP2 in ependymal cells regulates BMP signaling in the adult neurogenic niche. J. Cell Sci. 123, 1922-1930.

Gburek, J., Verroust, P. J., Willnow, T. E., Fyfe, J. C., Nowacki, W., Jacobsen, C., Moestrup, S. K., and Christensen, E. I. (2002). Megalin and cubilin are endocytic receptors involved in renal clearance of 
haemoglobin. J. Am. Soc. Nephrol. 13, 423-430.

Gerritsen, K. G., Peters, H. P., Nguyen, T. Q., Koeners, M. P., Wetsels, J. F., Joles, J. A., Christensen, E. I., Verroust, P. J., Li, D., Oliver, N., Xu, L., Kok, R. J., and Goldschmeding, R. (2010). Renal proximal tubular dysfunction is a major determinant of urinary connective tissue growth factor excretion. Am. J. Physiol. Renal Physiol. 298, 1457-1464.

Gonzalez-Villalobos, R., Klassen, R. B., Allen, P. L., Johanson, K., Baker, C. B., Kobori, H., Navar, L. G., and Hammond, T. G. (2006). Megalin binds and internalize angiotensin (1-7). Am. J. Physiol. Renal Physiol. 290, 1270-1275.

Gonzalez-Villalobos, R., Klassen, R. B., Allen, P. L., Navar, L. G., and Hammond, T. G. (2005). Megalin binds and intenalize angiotensin II. Am. J. Physiol. Renal Physiol. 288, 420-427.

Gotthardt, M., Trommsdorff, M., Nevitt, M. F., Shelton, J., Richardson, J. A., Stockinger, W., Nimpf, J., and Herz, J. (2000). Interactions of the low density lipoprotein receptor gene family with cytosolic adaptor and scaffold proteins suggest diverse biological functions in cellular communication and signal transduction. J. Biol. Chem. 275, 25616-25624.

Groot, A. J., and Vooijs, M. A. (2012). The role of Adams in Notch signaling. Adv. Exp. Med. Biol. 727, 15-36.

Hammad, S. M., Ranganathan, S., Loukinova, E., Twal, W. O., and Argraves, W. S. (1997). Interaction of apolipoprotein J-amyloid beta-peptide complex with low density lipoprotein receptor-related protein-2/megalin. A mechanism to prevent pathological accumulation of amyloid beta-peptide. J. Biol. Chem. 272, 18644-18649.

Hammes, A., Andreassen, T. K., Spoelgen, R., Raila, J., Hubner, N., Schulz, H., Metzger, J., Schweigert, F. J., Luppa, P. B., Nykjaer, A., and Willnow, T. E. (2005). Role of endocytoses in cellular uptake of sex steroids. Cell 122, 751-762.

Harold, D., Abraham, R., Hollingworth, P., Sims, R., Gerrish, A., Hamshere, M. L., Pahwa, J. S., Moskvina, V., Dowzell, K., Williams, A., Jones, N., Thomas, C., Stretton, A., Morgan, A. R., Lovestone, S., Powell, J., Proitsi, P., Lupton, M. K., Brayne, C., Rubinsztein, D. C., Gill, M., Lawlor, B., Lynch, A., Morgan, K., Brown, K. S., Passmore, P. A., Craig, D., McGuinness, B., Todd, S., Holmes, C., Mann, D.,
Smith, A. D., Love, S., Kehoe, P. G., Hardy, J., Mead, S., Fox, N. Rossor, M., Collinge, J., Maier, W., Jessen, F., Schürmann, B., van den Bussche, H., Heuser, I., Kornhuber, J., Wiltfang, J., Dichgans, M., Frölich, L., Hampel, H., Hüll, M., Rujescu, D., Goate, A. M., Kauwe, J. S., Cruchaga, C., Nowotny, P., Morris, J. C., Mayo, K., Sleegers, K., Bettens, K., Engelborghs, S., De Deyn, P. P., Van Broeckhoven, C., Livingston, G., Bass, N. J., Gurling, H., McQuillin, A., Gwilliam, R., Deloukas, P., Al-Chalabi, A., Shaw, C. E., Tsolaki, M., Singleton, A. B. Guerreiro, R., Mühleisen, T. W., Nöthen, M. M., Moebus, S., Jöckel, K. H., Klopp, N., Wichmann, H. E., Carrasquillo, M. M., Pankratz, V. S., Younkin, S. G., Holmans, P. A., O’Donovan, M., Owen, M. J., and Williams, J. (2009). Genome-wide association study identifies variants ar CLU and PICALM associated with Alzheimer's disease. Nat. Genet. 41, 1088-1093.

Hartz, A. M., Miller, D. S., and Bauer, B. (2010). Restoring blood-brain barrier P-glycoprotein reduces brain $\mathrm{A}\{$ beta $\}$ in a mouse model of Alzheimer's disease. Mol. Pharmacol. 77, 715-723.

Hass, M. R., Sato, C., Kopan, R., and Zhao, G. (2009). Presenilin: RIP and beyond. Semin. Cell Dev. Biol. 20, 201-210.

Hayashi, H., Campenot, R. B., Vance, D. E., and Vance, J. E. (2007). Apolipoprotein E-containing lipoproteins protect neurons from apoptosis via a signaling pathway involving low-density lipoprotein receptor-related protein-1. J. Neurosci. 27, 1933-1941.

Herz, J. (2001). The LDL receptor gene family: (un)expected signal transducers in the brain. Neuron 29, 571-581.

Herz, J., and Bock, H. H. (2002). Lipoprotein receptors in the nervous system. Annu. Rev. Biochem. 71, 405-434.

Herz, J., and Chen, Y. (2006). Reelin, lipoprotein receptors and synaptic plasticity. Nat. Rev. Neurosci. 7, 850-859.

Herz, J., Hamann, U., Myklebost, O., Gausepohl, H., and Stanley, K. K. (1988). Surface location and high affinity for calcium of a 500-kd liver membrane protein closely related to the LDL receptor suggest a physiological role as lipoprotein receptor. EMBO J. 7, 4119-4127.

Herz, J., and Strickland, D. K. (2001). LRP: a multifunctional scavenger and signaling receptor. J. Clin. Invest. 108, 779-784.
Herz, J., Chen, Y., Masiulis, I., and Zhou, L. (2009). Expanding functions of lipoprotein receptors. J. Lipid Res. 50, S287-S292.

Hey, P. J., Twells, R. C., Phillips, M S., Nakagawa, Y., Brown, S. D., Kawaguchi, Y., Cox, R., Guochun, X., Dugan, V., Hammond, H., Metzker, M. L., Todd, J. A., and Hess, J. F. (1998). Cloning of a novel member of the low-density lipoprotein receptor family. Gene 216, 103-111.

Hilpert, J., Nykjaer, A., Jacobsen, C. Wallukat, G., Nielsen, R., Moestrup, S. K., Haller, H., Luft, F. C. Christensen, E. I., and Willnow, T. E. (1999). Megalin antagonizes activation of the parathyroid hormone receptor. J. Biol. Chem. 274, 5620-5625.

Hoe, H. S., Harris, D. C., and Rebeck, G. W. (2005). Multiple pathways of apolipoprotein E signaling in primary neurons. J. Neurochem. 93, 145-155.

Hussain, M. M., Strickland, D. K. and Bakillah, A. (1999). The mammalian low-density lipoprotein receptor family. Annu. Rev. Nutr. 19, 141-172.

Hvidberg, V., Maniecki, M. B., Jacobsen, C., Hojrup, P., Moller, H. J., and Moestrup, S. K. (2005) Identification of the receptor scavenging hemopexin-heme complexes. Blood 106, 2572-2579.

Ishida, T., Hatae, T., Nishi, N., and Araki, N. (2006). Soluble megalin is accumulated in the lumen of the rat endolymphatic sac. Cell Struct. Funct. 31, 77-85.

Iwatsubo, T., Odaka, A., Suzuki, N., Mizusawa, H., Nukina, N., and Ihara, Y. (1994). Visualization of A beta 42 and A beta 40 in senile plaques with end-specific A beta monoclonals: evidence that an initially deposited species is A beta 42 . Neuron 13, 45-53.

Jakobsen, L., Madsen, P., Moestrup S. K., Lund, A. H., Tommerup, N., Nykjaer, A., Sottrup-Jensen, L., Gliemann, J., and Petersen, C. M. (1996). Molecular characterization of a novel human hybrid-type receptor that binds the alpha2-macroglobulin receptorassociated protein. J. Biol. Chem. 271, 31379-31383.

Jen, A., Parkyn, C. J., Mootoosamy, R. C., Ford, M. J., Warley, A., Liu, Q., Bu, G., Baskakov, I. V., Moestrup, S., McGuinness, L., Emptage, N., and Morris, R. J. (2010). Neuronal lowdensity lipoprotein receptor related protein 1 binds and endocytoses prion fibrils via receptor cluster 4 . J. Cell Sci. 123, 246-255.
Jeon, H., Meng, W., Takagi, J., Eck, M. J., Springer, T. A., and Blacklow, S. C. (2001). Implications for familial hypercholesterolemia from the structure of the LDL receptor YWTD-EGF domain pair. Nat. Struct. Biol. 8, 499-504.

Jin, M., Shepardson, N., Yang, T., Chen, G., Walsh, D., and Selkoe, D. (2011). Soluble amyloid beta protein dimers islolated from Alzheimer cortex directly induce Tau hyperphosphorylation and neuritic degeneration. Proc. Natl. Acad. Sci. U.S.A. 108, 5819-5824.

Kanalas, J. J., and Hopfer, U. (1997). Effect of TGF-beta 1 and TNFalpha on the plasminogen system of rat proximal tubular epithelial cells. J. Am. Soc. Nephrol. 8, 184-192.

Kanalas, J. J., and Makker, S. P. (1993). Analysis of a $45-\mathrm{kDa}$ protein that binds to the Heymann nephritis autoantigen GP330. J. Biol. Chem. 268, 8188-8192.

Kanekiyo, T., Zhang, J., Liu, Q., Liu, C. C., Zhang, L., and Bu, G. (2011). Heparan sulphate proteoglycan and the low density lipoprotein receptor related protein-1 constitute major pathways for neuronal amyloid-beta uptake. J. Neurosci. 31, 1644-1651.

Kaseda, R., Iino, N., Hosojima, M., Takeda, T., Hosaka, K., Kobayashi, A., Yamamoto, K., Suzuki, A., Kasai, A., Suzuki, Y., Gejyo, F., and Saito, A. (2007). Megalin mediated endocytoses of Cystatin C in proximal tubule cells. Biochem. Biophys. Res. Commun. 357, 1130-1134.

Katsouri, L., and Georgopoulos, S. (2011). Lack of LDL receptor enhances amyloid deposition and decreases glial response in an Alzheimer's disease mouse model. PLoS ONE 6:e21880. doi: 10.1371/ journal.pone.0021880

Kawata, K., Kubota, S., Eguchi, T., Aoyama, E., Morotani, N. H., Kondo, S., Nishida, T., and Takigawa, M. (2012). Role of low-density lipoprotein receptor related protein 1 (LRP1) in CCN2/connective tissue growth factor (CTGF) protein transport in chondrocytes. J. Cell Sci. doi: 10.1242/jcs.101956. [Epub ahead of print].

Kim, D. H., Iijima, H., Goto, K., Sakai, J., Ishii, H., Kim, H. J., Suzuki, H., Kondo, H., Saeki, S., and Yamamoto, T. (1996). Human apolipoprotein E receptor2. A novel lipoprotein receptor of the low density lipoprotein receptor family predominantly expressed in brain. J. Biol. Chem. 271, 8373-8380.

Kim, D. H., Inagaki, Y., Suzuki, T., Ioka, R. X., Yoshioka, S. Z., Magoori, 
K., Kang, M. J., Cho, Y., Nakano, A. Z., Liu, Q., Fujino, T., Suzuki, H., Sasano, H., and Yamamoto, T. T. (1998). A new low density lipoprotein receptor related protein, LRP5, is expressed in hepatocytes and adrenal cortex, and recognizes apolipoprotein E. J. Biochem. 124, 1072-1076.

Kinoshita, A., Shah, T., Tangredi, M. M., Strickland, D. K., and Hyman, B. T. (2003). The intracellular domain of the low density lipoprotein receptor-related protein modulates transactivation mediated by amyloid precursor protein and Fe65. J. Biol. Chem. 278, 41182-41188.

Kinoshita, A., Whelan, C. M., Smith, C. J., Mikhailenko, I., Rebeck, G. W., Strickland, D. K., and Hyman, B. T. (2001). Demonstration by fluorescence resonance energy transfer of two sites of interaction between the low-density lipoprotein receptor-related protein and the amyloid precursor protein: role of the intracellular adapter protein Fe65. J. Neurosci. 21, 8354-8361.

Klassen, R. B., Crenshaw, K., Kozyraki, R., Verroust, P. J., Tio, L., Atrian, S., Allen, P. L., and Hammond, T. G. (2004). Megalin mediates renal uptake of heavy metal metallothionein complexes. Am. J. Physiol. Renal Physiol. 287, 393-403.

Klug, W., Dietl, A., Simon, B., Sinning, I., and Wild, K. (2011). Phosphorylation of LRP1 regulates the interaction with Fe65. FEBS Lett. 585, 3229-3235.

Knauer, M. F., Orlando, R. A., and Glabe, C. G. (1996). Cell surface APP751 forms complexes with protease nexin 2 ligands and is internalized via the low density lipoprotein receptor-related protein (LRP). Brain Res. 740, 6-14.

Kounnas, M. Z., Danks, A. M., Cheng, S., Tyree, C., Ackerman, E., Zhang, X., Ahn, K., Nguyen, P., Comer, D., Mao, L., Yu, C., Pleynet, D., Digregorio, P. J., Velicelebi, G., Stauderman, K. A., Comer, W.T., Mobley, W. C., Li, Y. M., Sisodia, S. S., Tanzi, R. E., and Wagner, S. L. (2008). Modulation of gammasecretase reduces beta-amyloid deposition in a transgenic mouse model of Alzheimer's disease. Neuron 67, 769-780.

Kounnas, M. Z., Henkin, J., Argraves, W. S., and Strickland, D. K. (1993). Low density lipoprotein receptor-related protein/alpha 2-macroglobulin receptor mediates cellular uptake of pro-urokinase. $J$. Biol. Chem. 268, 21862-21867.
Kounnas, M. Z., Moir, R. D., Rebeck, G. W., Bush, A. I., Tanzi, R. E. Hyman, B. T., and Strickland, D. K. (1995). LDL receptor-related protein, a multifunctional ApoE receptor, binds secreted beta-amyloid precursor protein and mediates its degradation. Cell 82, 331-340.

LaFerla, F. M., Troncoso, J. C., Strickland, D. K., Kawas, C. H., and Jay, G. (1997). Neuronal cell death in Alzheimer's disease correlates with apoE uptake and intracellular Abeta stabilization. J. Clin. Invest. 100, 310-320.

Larsson, M., Hjalm, G., Sakwe, A. M., Engstrom, A., Hoglund, A. S., Larsson, E., Robinson, R. C., Sundberg, G., and Rask, L. (2003). Selective interaction of megalin with postsynaptic density-95 (PSD-95)-like membrane-associated guanylate kinase (MAGUK) proteins. Biochem. J. 373, 381-391.

Lee, S. H., Suh, H. N., Lee, Y. J., Seo, B. N., Ha, J. W., and Han, H. J. (2012). Midkine prevented pypoxic injury of mouse embryonic stem cells through activation of Akt and HIF-1a via low density lipoprotein receptor related protein 1. J. Cell. Physiol. 227, 1731-1739.

Leheste, J. R., Rolinski, B., Vorum, H., Hilpert, J., Nykjaer, A., Jacobsen, C., Aucouturier, P., Moskaug, J. O., Otto, A., Christensen, E. I., and Willnow, T. E. (1999). Megalin knockout mice as an animal model of low molecular weight proteinuria. Am. J. Pathol. 155, 1361-1370.

Li, Y., Cong, R., and Biemesderfer, D. (2008). The $\mathrm{COOH}$ terminus of megalin regulates gene expression in opossum kidney proximal tubule cells. Am. J. Physiol. Cell Physiol. 295, 529-537.

Li, Y., Lu, W., Marzolo, M. P., and Bu, G. (2001). Differential functions of members of the low density lipoprotein receptor family suggested by their distinct endocytosis rates. J. Biol. Chem. 276 18000-18006.

Li, Y., Marzolo, M. P., van Kerkhof, P. Strous, G. J., and Bu, G. (2000). The YXXL motif, but not the two NPXY motifs, serves as the dominant endocytosis signal for low density lipoprotein receptorrelated protein. J. Biol. Chem. 275, 17187-17194.

Lighthouse, J. K., Zhang, L., Hsieh, J. C., Rosenquist, T., and Holdener, B. C. (2010). MESD is essential for apical localization of megalin/LRP2 in the visceral endoderm. Dev. Dyn. 240, 577-588.
Lillis, A. P., van Duyn, L. B., MurphyUllrich, J. E., and Strickland, D. K. (2008). LDL receptor-related protein 1 , unique tissue-specific functions revealed by selective gene knockout studies. Physiol. Rev. 88, 887-918.

Liu, C. X., Musco, S., Lisitsina, N. M., Yaklichkin, S. Y., and Lisitsyn, N. A. (2000). Genomic organization of a new candidate tumor suppressor gene, LRP1B. Genomics 69 271-274.

Mahley, R. W., and Ji, Z. S. (1999) Remnant lipoprotein metabolism: key pathways involving cell-surface heparin sulfate proteoglycans and apolipoprotein E. J. Lipid Res. 40, $1-16$.

Makarova, A., Mikhailenko, I., Bugge, T. H., List, K., Lawrence, D. A., and Strickland, D. K. (2003). The low density lipoprotein receptorrelated protein modulates protease activity in the brain by mediating the cellular internalization of both neuroserpin and neuroserpintissue-type plasminogen activator complexes. J. Biol. Chem. 278, 50250-50258.

Martínez-García, A., Sastre, I., Recuero, M., Aldudo, J., Vilella, E., Mateo, I., Sánchez-Juan, P., Vargas, T., Carro, E., Bermejo-Pareja, F., RodríguezRodríguez, E., Combarros, O. Rosich-Estrago, M., Frank, A., Valdivieso, F., and Bullido, M. J. (2010). PLA2G3, a gene involved in oxidative stress induced death, is associated with Alzheimer's disease. J. Alzheimers Dis. 22, 1181-1187.

Marzolo, M. P., von, B. R., Bu, G., and Inestrosa, N. C. (2000). Expression of alpha(2)-macroglobulin receptor/low density lipoprotein receptor-related protein (LRP) in rat microglial cells. J. Neurosci. Res. 60, 401-411.

Marzolo, M. P., Yuseff, M. I., Retamal, C., Donoso, M., Ezquer, F., Farfan, P., Li, Y., and Bu, G. (2003). Differential distribution of low-density lipoproteinreceptor-related protein (LRP) and megalin in polarized epithelial cells is determined by their cytoplasmic domains. Traffic 4, 273-288.

Mauch, D. H., Nägler, K., Schumacher, S., Göritz, C., Müller, E. C., Otto, A., and Pfrieger, F. W. (2001). CNS synaptogenesis promoted by glia received cholesterol. Science 294, 1354-1357.

May, P., Reddy, Y. K., and Herz, J. (2002). Proteolytic processing of low density lipoprotein receptorrelated protein mediates regulated release of its intracellular domain. J. Biol. Chem. 277, 18736-18743.

May, P., Bock, H. H., Nimpf, J., and Herz, J. (2003). Differential glycosylation regulates processing of lipoprotein receptors by gamma secretase. J. Biol. Chem. 278, 37386-37392.

May, P., Rohlmann, A., Bock, H. H., Zurhove, K., Marth, J. D., Schomburg, E. D., Noebels, J. L., Beffert, U., Sweatt, J. D., Weeber, E. J., and Herz, J. (2004). Neuronal LRP1 functionally associates with postsynaptic proteins and is required for normal motor function in mice. Mol. Cell. Biol. 24, 8872-8883.

Meijer, A. B., Rohlena, J., van der Zwaan, C., van Zonneveld, A. J. Boertjes, R. C., Lenting, P. J., and Mertens, K. (2007). Functional duplication of ligand-binding domains within low-density lipoprotein receptor-related protein for interaction with receptor associated protein, alpha2macroglobulin, factor IXa and factorVIII. Biochim. Biophys. Acta 1774, 714-722.

Moestrup, S. K., and Verroust, P. J. (2001). Megalin and cubilin mediated endocytosis of protein bound vitamins, lipids, and hormones in polarized epithelia. Annu. Rev. Nutr. 21, 407-428.

Neels, J. G., van den Berg, B. M. M., Lookene, A., Olivecrona, G., Pannekoek, H., and van Zonneveld, A. J. (1999). The second and fourth cluster of class A cysteine-rich repeats of the low density lipoprotein receptor-related protein share ligand-binding properties. J. Biol. Chem. 274, 31305-31311.

Nielsen, R., Courtoy, P. J., Jacobsen, C., Dom, G., Lima, W. R., Jadot, M., Willnow, T. E., Devuyst, O., and Christensen, E. I. (2007). Endocytosis provides a major alternative pathway for lysosomal biogenesis in kidney proximal tubular cells. Proc. Natl. Acad. Sci. U.S.A. 104, 5407-5412.

Nieoullon, A. (2011). Neurodegenerative diseases and neuroprotection: current views and prospects. J. Appl. Biomed. 9, 173-183.

Niu, S., Yabut, O., and D'Arcangelo, G. (2008). The reelin signaling pathway promotes dendritic spine development in hippocampal neurons. J. Neurosci. 28, 10339-10348.

Novak, S., Hiesberger, T., Schneider, W. J., and Nimpf, J. (1996). A new low density lipoprotein receptor homologue with 8 ligand binding repeats in brain of chicken 
and mouse. J. Biol. Chem. 271, 11732-11736.

Nuutinen, T., Suuronen, T., Kauppinen, A., and Salminen, A. (2009). Clusterin: a forgotten player in Alzheimer's disease. Brain Res. Rev. 61, 89-104.

Nykjaer, A., Dragun, D., Walther, D., Vorum, H., Jacobsen, C., Herz, J., Melsen, F., Christensen, E. I., and Willnow, T. E. (1999). An endocytic pathway essential for renal uptake and activation of the steroid 25- $(\mathrm{OH})$ vitamin D3. Cell 96, 507-515.

Obermoeller-McCormick, L. M., Li, Y., Osaka, H., FitzGerald, D. J., Schwartz, A. L., and Bu, G. (2001). Dissection of receptor folding and ligand binding property with functional minireceptors of LDL receptor-related protein. J. Cell Sci. 114, 899-908.

Olson, G. E., Winfrey, V. P., Hill, K. E., and Burk, R. F. (2008). Megalin mediates selenoprotein $\mathrm{P}$ uptake by kidney proximal tubule epithelial cells. J. Biol. Chem. 283, 6854-6860.

Orlando, R. A., Rader, K., Authier, F., Yamazaki, H., Posner, B. I., Bergeron, J. J., and Farquhar, M. G. (1998). Megalin is an endocytic receptor for insulin. J. Am. Soc. Nephrol. 9, 1759-1766.

Oyama, Y., Takeda, T., Hama, H., Tanuma, A., Iino, N., Sato, K., Kaseda, R., Ma, M., Yamamoto, T., Fujii, H., Kazama, J. J., Odani, S., Terada, Y., Mizuta, K., Gejyo, F., and Saito, A. (2005). Evidence for megalin mediated proximal tubular uptake of L-FABP, a carrier of potentially nephrotoxic molecules. Lab. Invest. 85, 522-531.

Parkyn, C. J., Vermeulen, E. G. M., Mootoosamy, R. C., Sunyach, C., Jacobsen, C., Oxvig, C., Moestrup, S., Liu, Q., Bu, G., Jen, A., and Morris, R. J. (2008). LRP1 controls biosynthetic and endocytic trafficking of neuronal prion protein. J. Cell Sci. 121, 773-783.

Patrie, K. M., Atyrie, K. M., Drescher, A. J., Goyal, M., Wiggins, R. C., and Margolis, B. (2001). The membrane-associated guanylate kinase protein MAGI-1 binds megalin and is present in glomerular podocytes. J. Am. Soc. Nephrol. 12, 667-677.

Pflanzner, T., Janko, M. C., AndréDohmen, B., Reuss, S., Weggen, S., Roebroek, A. J., Kuhlmann, C. R., and Pietrzik, C. U. (2011). LRP1 mediates bidirectional transcytosis of amyloid- $\beta$ across the bloodbrain barrier. Neurobiol. Aging 32, 2323.e1-2323.e11.
Pfrieger, F. W. (2003). Cholesterol homeostasis and function in neurons of the central nervous system. Cell. Mol. Life Sci. 60, 1158-1171.

Pietrzik, C. U., Busse, T., Merriam, D. E., Weggen, S., and Koo, E. H. (2002). The cytoplasmic domain of the LDL receptor-related protein regulates multiple steps in APP processing. EMBO J. 21, 5691-5700.

Pietrzik, C. U., Yoon, I. S., Jaeger, S., Busse, T., Weggen, S., and Koo, E. H. (2004). FE65 constitutes the functional link between the low-density lipoprotein receptor-related protein and the amyloid precursor protein. J. Neurosci. 24, 4259-4265.

Poon, G. M., and Gariepy, J. (2007). Cell-surface proteoglycans as molecular portals for cationic peptide and polymer entry into cells. Biochem. Soc. Trans. 35, 788-793.

Qiu, Z., Crutcher, K. A., Hyman, B. T., and Rebeck, G. W. (2003). ApoE isoforms affect neuronal N-methylD-aspartate calcium responses and toxicity via receptor-mediated processes. Neuroscience 122, 291-303.

Qiu, Z., Strickland, D. K., Hyman, B. T., and Rebeck, G. W. (2002). Alpha 2-macroglobulin exposure reduces calcium responses to $\mathrm{N}$-methyl-daspartate via low density lipoprotein receptor-related protein in cultured hippocampal neurons. J. Biol. Chem. 277, 14458-14466.

Rader, K., Orlando, R. A., Lou, X., and Farquar, M. G. (2000). Characterization of ANKRA, a novel ankyrin repeat protein that interacts with the cytoplasmic domain of megalin. J. Am. Soc. Nephrol. 11, 2167-2178.

Ranganathan, S., Knaak, C., Morales, C. R., and Argraves, W. S. (1999). Identification of low density lipoprotein receptor related protein$2 /$ megalin as an endocytic receptor for seminal vesicle secretory protein II. J. Biol. Chem. 274, 5557-5563.

Ranganathan, S., Noyes, N. C., Migliorini, M., Winkles, J. A., Battey, F. D., Hyman, B. T., Smith, E., Yepes, M., Mikhailenko, I., and Strickland, D. K. (2011). LRAD3, a novel low-density lipoprotein receptor family member that modulates amyloid precursor protein trafficking. J. Neurosci. 31, 10836-10846.

Rebeck, G. W., Harr, S. D., Strickland, D. K., and Hyman, B. T. (1995). Multiple, diverse senile plaqueassociated proteins are ligands of an apolipoprotein E receptor, the alpha 2-macroglobulin receptor/lowdensity-lipoprotein receptor related protein. Ann. Neurol. 37, 211-217.
Rebeck, G. W., Moir, R. D., Mui, S., Strickland, D. K., Tanzi, R. E., and Hyman, B. T. (2001) Association of membrane-bound amyloid precursor protein APP with the apolipoprotein E receptor LRP. Brain Res. Mol. Brain Res. 87, 238-245.

Sagare, A. P., Deane, R., Zetterberg, H., Wallin, A., Blennow, K., and Zlokovic, B. V. (2011a). Impaired lipoprotein receptor-mediated peripheral binding of plasma amyloid- $\beta$ is an early biomarker for mild cognitive impairment preceding Alzheimer's disease. J. Alzheimers Dis. 24, 25-34.

Sagare, A. P., Winkler, E. A., Bell, R. D., Deane, R., and Zlokovic, B. V. (2011b). From liver to the blood brain barrier: an interconnected system regulating brain amyloid-beta levels. J. Neurosci. Res. 89, 967-968.

Saito, A., Pietromonaco, S., Loo, A. K., and Farquhar, M. G. (1994) Complete cloning and sequencing of rat gp330/“megalin,” a distinctive member of the low density lipoprotein receptor gene family. Proc. Natl. Acad. Sci. U.S.A. 91, 9725-9729.

Selkoe, D., Mandelkow, E., and Holtzman, D. (2012). Deciphering Alzheimer's disease. Cold Spring Harb. Perspect. Med. 2, a011460.

Selvais, C., D’Auria, L., Tyteca, D. Perrot, G., Lemoine, P., Troeberg, L., Dedieu, S., Noël, A., Nagase, H., Henriet, P., Courtoy, P. J., Marbaix, E., and Emonard, $\mathrm{H}$ (2011). Cell cholesterol modulates metalloproteinase-dependent shedding of low densisty lipoprotein receptor related protein-1 (LRP-1) and clearance function. FASEB J. 25 , 2770-2781.

Shi, H., Belbin, O., Medway, C., Brown, K., Kalsheker, N., Carrasquillo, M., Proitsi, P., Powell, J., Lovestone, S., Goate, A., Younkin, S., Passmore, P., and Genetic and Enviromental risk for Alzheimer's disease (GERAD1) Consortium, Morgan, K., Alzheimer's research UK (ARUK) Consortium. (2012). Genetic variants influencing human aging from late-onset alzheimer's disease (LOAD) genome-wide association studies (GWAS). Neurobiol. Aging 33, 1849e5-1849e18.

Shibata, M., Yamada, S., Kumar S. R., Calero, M., Bading, J., Frangione, B., Holtzman, D. M., Miller, C. A., Strickland, D. K., Ghiso, J., and Zlokovic, B. V. (2000) Clearance of Alzheimer's amyloid-ss (1-40) peptide from brain by LDL receptor-related protein-1 at the blood-brain barrier. J. Clin. Invest. 106, 1489-1499.
Sousa, M. M., Norden, A. G., Jacobsen, C., Willnow, T. E., Christensen, E. I., Thakker, R. V., Verroust, P. J., Moestrup, S. K., and Saraiva, M. J. (2000). Evidence for the role of megalin in renal uptake of transthyrretin. J. Biol. Chem. 275, 38176-38181.

Spoelgen, R., Hammes, A., Anzenberger, U., Zechner, D. Andersen, O. M., Jerchow, B., and Willnow, T. E. (2005). LRP2/Megalin is required for patterning of the ventral telencephalon. Development 132, 405-414.

Spuch, C., and Carro, E. (2011). The p75 neurotrophin receptor localization in blood CSF barrier: expression in choroid plexus epithelium. BMC Neurosci. 12, 39.

Spuch, C., Diz-Chaves, Y., Pérez-Tilve, D., and Mallo, F. (2004). Heparin increases prolactin and modifies the effects of FGF-2 upon prolactin accumulation in pituitary primary cultures. Endocrine 24, 131-136.

Spuch, C., Diz-Chaves, Y., Pérez-Tilve, D., and Mallo, F. (2006). Fibroblast growth factor-2 and eipidermal growth factor modulate prolactin responses to TRH and dopamine in primary cultures. Endocrine 29, 317-324.

Spuch, C., and Navarro, C. (2010a). Expression and functions of LRP-2 in central nervous system: progress in understanding its regulation and the potential use for treatment of neurodegenerative diseases. Immunol. Endocr. Metab. Agents Med. Chem. 10, 249-254.

Spuch, C., and Navarro, C. (2010b). Transport Mechanisms at the Blood-Cerebrospinal-Fluid Barrier: role of Megalin (LRP2). Recent Patents Endocr. Metab. Immune Drug Discov. 4, 190-205.

Stefansson, S., Chappell, D. A., Argraves, K. M., Strickland, D. K., and Argraves, W. S. (1995). Glycoprotein 330/low density lipoprotein receptor related protein 2 mediates endocytoses of low dendity lipoproteins via interaction with apolipoprotein B100. J. Biol. Chem. 270, 19417-19421.

Takakashi, S., Kawarabayasi, Y., Nakai, T., Sakai, J., and Yamamoto, T. (1992). Rabbit very low density lipoprotein receptor: a lowdensity lipoprotein receptor-like protein with distinct ligand specificity. Proc. Natl. Acad. Sci. U.S.A. 89, 9252-9256.

Tasaki, T., and Kwon, Y. T. (2007). The mammalian $\mathrm{N}$-end rule pathway: new insights into its components and physiological roles. Trends Biochem. Sci. 32, 520-528. 
Taylor, D. R., and Hooper, N. M. (2007). The low density lipoprotein receptor-releated protein 1 (LRP1) mediates the endocytoses of the cellular prion protein. Biochem. J. 402, 17-23.

Trommsdorff, M., Borg, J. P., Margolis, B., and Herz, J. (1998). Interaction of cytosolic adaptor proteins with neuronal apolipoprotein $\mathrm{E}$ receptors and the amyloid precursor protein. J. Biol. Chem. 273, 33556-33560.

Trommsdorff, M., Gotthardt, M., Hiesberger, T., Shelton, J., Stockinger, W., Nimpf, J., Hammer, R. E., Richardson, J. A., and Herz, J. (1999). Reeler/Disabled-like disruption of neuronal migration in knockout mice lacking the VLDL receptor and ApoE receptor 2. Cell 97, 689-701.

van der Geer, P. (2002). Phosphorylation of LRP1, regulation of transport and signal transduction. Trends Cardiovasc. Med. 12, 160-165.

van Horssen, J., Wesseling, P., van den Heuvel, L. P., de Waal, R. M., and Verbeek, M. M. (2003). Heparan sulphate proteoglycans in Alzheimer's disease and amyloidrelated disorders. Lancet Neurol. 2, 482-492.

Vargas, T., Antequera, D., Ugalde, C., Spuch, C., and Carro, E. (2010a). Gelsolin restores A beta induced alterations in choroid plexus. J. Biomed. Biotechnol. 2010, 805405.

Vargas, T., Bullido, M. J., MartinezGarcia, A., Antequera, D., Clarimon, J., Rosich-Estrago, M., MartinRequero, A., Mateo, I., RodriguezRodriguez, E., Vilella-Cuadrada, E., Frank, A., Lleo, A., MolinaPorcel, L., Blesa, R., Combarros, O., Gomez-Isla, T., Bermejo-Pareja, F., Valdivieso, F., and Carro, E. (2010b). A megalin polymorphism associated with promoter activity and Alzheimer's disease risk. Am. J. Med. Genet. B Neuropsychiatr. Genet. 153B, 895-902.

Vargas, T., Martinez-Garcia, A., Antequera, D., Vilella, E., Clarimon, J., Mateo, I., Sanchez-Juan, P.,
Rodriguez-Rodriguez, E., Frank, A., Rosich-Estrago, M., Lleo, A., Molina-Porcel, L., Blesa, R., Gomez-Isla, T., Combarros, O., Bermejo-Pareja, F., Valdivieso, F., Bullido, M. J., and Carro, E. (2011). IGF-I gene variability is associated with an increased risk of AD. Neurobiol. Aging 556, e3-e11.

Vasquez-Higuera, J. L., Mateo, I., Sánchez-Juan, P., RodríguezRodríguez, E., Pozueta, A., Infante, J., Berciano, J., and Combarros, O. (2009). Genetic interaction between tau and the apolipoprotein E receptor LRP1 increases Alzheimer's disease risk. Dement. Geriatr. Cogn. Disord. 28, 116-120.

von Einem, B., Schwanzar, D., Rehn, F., Beyer, A. S., Weber, P., Wagner, M., Schneckenburger, H., and von Arnim, C. A. (2010). The role of low density receptor related protein (LRP1) as a competetive substrate of the amyloid precursor protein (APP) for BACE1. Exp. Neurol. 225, 85-93.

Waldron, E., Heilig, C., Schweitzer, A., Nadella, N., Jaeger, S., Martin, A. M., Weggen, S., Brix, K., and Pietrzik, C. U. (2008). LRP1 modulates APP trafficking along early compartments of the secretory pathway. Neurobiol. Dis. 31, 188-197.

Willnow, T. E. (1999). The lowdensity lipoprotein receptor gene family: multiple roles in lipid metabolism. J. Mol. Med. 77, 306-315.

Wilsie, L. C., and Orlando, R. A. (2003). The low density lipoprotein receptor-related protein complexes with cell surface heparan sulfate proteoglycans to regulate proteoglycan-mediated lipoprotein catabolism. J. Biol. Chem. 278, 15758-15764.

Wolff, N. A., Lee, W. K., Abouhamed, M., and Thevenod, F. (2008). Role of ARF6 in internalization of metal-binding proteins, metallothionein and transferrin, and cadmium-metallothionein toxicity in kidney proximal tubule cells.
Toxicol. Appl. Pharmacol. 230, 78-85.

Yamazaki, H., Bujo, H., Kusunoki, J., Seimiya, K., Kanaki, T., Morisaki, N., Schneider, W. J., and Saito, Y. (1996). Elements of neural adhesion molecules and a yeast vacuolar protein sorting receptor are present in a novel mammalian low density lipoprotein receptor family member. J. Biol. Chem. 271, 24761-24768.

Yuseff, M. I., Farfan, P., Bu, G. and Marzolo, M. P. (2007). A cytoplasmic PPPSP motif determines megalin's phosphorylation and regulates receptor's recycling and surface expression. Traffic 8, 1215-1230.

Zarbalis, K., May, S. R., Shen, Y. Ekker, M., Rubenstein, J. L. R., and Peterson, A. S. (2004). A focused and efficient genetic screening strategy in the mouse: identification of mutations that disrupt cortical development. PLoS Biol. 2, 1179-1187.

Zheng, G., Bachinsky, D. R., Stamenkovic, I., Strickland, D. K., Brown, D., Andres, G., and McKluskey, R. T. (1994). Organ distribution in rats of two members of the low-density lipoprotein receptor gene family, gp330 and LRP/alpha $2 \mathrm{MR}$, and the receptor-associated protein (RAP). J. Histochem. Cytochem. 42, 531-542.

Zheng, G., Marino, M., Zhao, J., and McCluskey, R. T. (1998). Megalin (gp330): a putative endocytic receptor for thyroglobulin ( $\mathrm{Tg}$ ). Endocrinology 139, 1462-1465.

Zilberberg, A., Yaniv, A., and Gazit, A. (2004). The low density lipoprotein receptor-1, LRP1, interacts with the human frizzled-1 (HFzl) and down-regulates the canonical Wnt signaling pathway. J. Biol. Chem. 279, 17535-17542.

Zlokovic, B. V. (2004). Clearing amyloid through the bloodbrain barrier. J. Neurochem. 89, 807-811.

Zlokovic, B. V. (2011). Neurovascular pathways to neurodegeneration in Alzheimer's disease and other disorders. Nat. Rev. Neurosci. 12, 723-738.

Zlokovic, B. V., Deane, R., Sagare, A. P., Bell, R. D., and Winkler, E. A. (2010). Lowm density lipoprotein receptor related protein-1, a serial clearance homeostatic mechanism controlling Alzheimer's amyloid beta peptide elimination from the brain. J. Neurochem. 115, 1077-1089.

Zou, Z., Chung, B., Nguyen, T., Mentone, S., Thompson, B., and Biemesderfer, D. (2004). Linking receptor-mediated endocytosis and cell signaling: evidence for regulated intramembrane proteolysis of megalin in proximal tubule. J. Biol. Chem. 279, 34302-34310.

Zurhove, K., Nakajima, C., Herz, J., Bock, H. H., and May, P. (2008). Gamma-secretase limits the inflammatory response through the processing of LRP1. Sci. Signal. 47, ral5.

Conflict of Interest Statement: The authors declare that the research was conducted in the absence of any commercial or financial relationships that could be construed as a potential conflict of interest.

Received: 14 May 2012; accepted: 26 June 2012; published online: 16 July 2012.

Citation: Spuch C, Ortolano $S$ and Navarro C (2012) LRP-1 and LRP-2 receptors function in the membrane neuron. Trafficking mechanisms and proteolytic processing in Alzheimer's disease. Front. Physio. 3:269. doi: 10.3389/fphys. 2012.00269

This article was submitted to Frontiers in Membrane Physiology and Biophysics, a specialty of Frontiers in Physiology. Copyright (c) 2012 Spuch, Ortolano and Navarro. This is an open-access article distributed under the terms of the Creative Commons Attribution License, which permits use, distribution and reproduction in other forums, provided the original authors and source are credited and subject to any copyright notices concerning any third-party graphics etc. 